\title{
Chapter 7 \\ Knowledge Environments at Universities: Some Theoretical and Methodological Considerations
}

\author{
Peter Meusburger
}

\section{The Spatiality of Learning, Research, and Academic Careers}

Until the early 1980s most research on scientific creativity had focused on the personal attributes of scholars. Few authors found it necessary for their theoretical considerations to include the social, cultural, and scientific environment - the seat of socialization, learning, control, and encouragement by supervisors, research activities, and creative processes. Spatial differences in scientific practices and research cultures; spatial inequalities of career opportunities, financial resources, academic freedom, and other factors influencing the scientific achievements of scholars; and the attractiveness and reputation of universities received little attention. Science was assumed to be placeless. At best, it was admitted that talented individuals could not develop their creativity in repressive societies.

In the 1980s and 1990s researchers studying creativity increasingly accepted that talent, wealth of ideas, motivation, endurance, and other personal traits are not the only factors influencing how well a person's scholarly pursuits and academic career develops. What people call creative is never the result of individual action alone. The talented student and the creative scientist do not work in a social, cultural, and economic vacuum. A stimulating knowledge environment and a talented individual must come together and interact before a creative process can occur (Amabile, 1979, 1983a, 1983b, 1996; Amabile, Conti, Coon, Lazenby, \& Herron, 1996; Amabile, Goldfarb, \& Brackfield, 1990; Amabile, \& Gryskiewicz, 1989; Hennessey \& Amabile, 1988; Meusburger, 2009; Sternberg \& Lubart, 1991, 1999). No one can study scientific achievements and academic careers effectively by isolating scholars and their works from the political, social, cultural, and historical milieus in which

This chapter greatly expands on Meusburger $(2015,2016)$.

P. Meusburger $(\bowtie)$

Department of Geography, Heidelberg University, Heidelberg, Germany 
their academic socialization and research has taken place and in which their achievements have been evaluated, legitimated, or rejected by evaluators and gate-keepers of their research field.

A second line of arguments underlining the importance of places, settings, environments, and spatial relations for research and scientific careers has been put forward by the geography of science (Livingstone, 1995, 2000, 2002, 2003; Withers, 2001, 2002, 2010; Withers, Higgitt, \& Finnegan, 2008) and science studies in other disciplines (Collins, 1983, 2008; Collins \& Evans, 2002; Collins \& Pinch, 1998; Gieryn, 1983, 2000, 2002; Knorr-Cetina, 1999; Matthiesen, 2006, 2007). "Scientific knowledge is a geographical phenomenon. It is acquired in specific sites; it circulates from location to location; it transforms the world" (Livingstone, 2010, p. 18). The geography of science is interested in a variety of questions: Why has a specific research field first developed at university A and not at universities B or C? Why have some universities produced and attracted a host of outstanding scholars, whereas others have not? Which factors, expectations, or institutional logics inhibit or promote the scientific creativity and academic career of scholars? Why do scientific results travel in the selective way they do? Why does it sometimes take decades until outstanding scientific findings are accepted by other scholars? Why have important texts been read and interpreted so differently in specific places and environments? What can and cannot be said in particular venues? What effects do political power, cultural politics, and the geopolitics of science have on the generation and spatial diffusion of science? Why have outstanding centers of research lost their importance in the course of history? How do international networks of scientists evolve and which long-term consequences do they have? What are the preconditions and primary sources of paradigmatic change in various disciplines and places of science? Which local (regional) barriers and facilitators of change can be identified?

A third strand of arguments paving the way for research on the effects that environments have on action and performance originated in organizational research, business studies, and institutional theory. Scholars in these fields became interested in the psychological climate of organizations, in institutional logics, in rules and informal norms that structure behavior, and in organizational learning (Battilana, 2006; Berthoin Antal, Meusburger, \& Suarsana, 2014; Bitektine \& Miller, 2015; Cummings, 1965; Denison, 1996; Glückler, Lazega, \& Hammer, 2017; Lawrence, Suddaby, \& Leca, 2011; Mintzberg, 1979; Suddaby, 2010; Suddaby \& Greenwood, 2005). They found that creative persons are keenly sensitive and responsive to formal and informal sets of mutual expectations between people, to quality conventions and assessment tools prevailing at their place of work. Institutional theorists have recognized the constraining effect that institutional norms, conventions, and meaning systems have on the emergence of new theories, new research paradigms, and research methods (Bitektine \& Miller, 2015, p. 117). Some authors in organizational studies have discussed the social construction of fields (Fligstein, 2013), inhibitory constraints in organizational behavior (Lind \& van den Bos, 2013), adaptive leadership theory (DeRue, 2011), the influence of local communities on organizations (Marquis \& Battilana, 2009), and implications of the physical work environment on organizations (Zhong \& House, 2012). 
A key contribution came, fourth, from environmental psychology (Barker, 1968; Bechtel, 1997; Graumann, 1978, 2002a, 2002b, 2002c; Graumann \& Kruse, 1990, 2003; Kruse, 1986). Environmental psychologists no longer saw the behavior of the individual agent as the main focus of research in psychology. They were convinced that a behavior could be predicted more from knowledge about the spatiomaterial and social situation in which it occurs than from the knowledge and traits of the actor (Kruse, 1986, p. 135). Further insights have come from psychological studies on complex problem-solving, the decisive role that the environment has in it, the limitations of the corresponding psychological experiments, the tensions between field and laboratory research, and the contextual dependency of strategies (Dörner \& Funke, 2017, pp. 4-5; Funke, 2012; Runco, 1994; Runco \& Okuda, 1988).

$[T]$ here is no strategy that is so universal that it can be used in many different problem situations. . . Complex phenomena require complex approaches to understand them. The complex nature of complex systems imposes limitations on psychological experiments: The more complex the environments, the more difficult is it to keep conditions under experimental control. (Dörner \& Funke, 2017, pp. 4-5)

Fifth, since the 1980s human geography has developed new concepts of space and place that have facilitated interfaces with the social and behavioral sciences and have helped avoid spatial determinism and ecological fallacies (Harvey, 1969, 2005; Klüter, 1986, 1999, 2003; Lefebvre, 1974/1991; Lippuner, 2005; Lippuner \& Lossau, 2004; Massey, 1985, 1999a, 1999b, 2005; Meusburger, 2008; Meusburger \& Werlen, 2017; Schmid, 2005; Soja, 1980, 1985; Weichhart, 1996, 1999, 2003; Werlen, 1983, 1987, 1993, 1995, 1996, 1997a, 1997b, 2010a, 2010b).

A place can be defined as a "discursively constructed setting" (Feld \& Basso, 1996, p. 5) having a symbolic and emotional meaning; providing an identity; and communicating a complex history of events, cultural memories, and emotional attachments (Canter, 1977; Furnham, 1985; Giddens, 1984; Manzo, 2005; Rowles, 2008a, 2008b; Scannel \& Gifford, 2010; Werlen, 1983, 1987, 1997a). People are rooted in and attached to places, and places are "metaphorically tied to identities" (Feld \& Basso, 1996, p. 11). A place of work often signifies social status or a position in a hierarchy.

Place names of famous universities serve as a kind of shorthand or metonomy ${ }^{1}$ for the inscrutable complexity of research processes taking place at these locations. The achievements and academic reputation earned by generations of individual scholars are ascribed to or projected onto their university. Through these projections, university locations become symbolically charged. Because nobody can unravel the complexity of interaction, learning processes, and institutional decision-making, the appraisal of a scientist's potential is closely tied to the places at which that

\footnotetext{
${ }^{1}$ A metonomy is a figure of speech in which a word, phrase, thing, or concept is substituted for another with which it is closely associated. When people refer to complex and nontransparent situations, they often use place names. Wall Street stands for the worldwide center of financial services; Berlin, for the government of Germany; and Berkeley, Stanford, or Cambridge, for outstanding levels of science.
} 
person earned his or her doctorate, did postdoctoral work, or received an offer of a professorship. A scholar who has been trained at a distinguished research department has credibility from the outset because the scientific reputation of a place or institution reflects on the scholars working there. The scientific reputation built by scientific institutions stems from their ability to appoint the best candidates available. The identity of scholars is defined not only by what they do but also by where they do it. The scientific career of most scholars is distributed across more than one university. However, the move from one university to the next is rarely random; it is rather a "contingent series of events" (Welskopp, 2002, p. 79) ${ }^{2}$ that follow a definite logic and stem from particular mechanisms.

A place is like a screen on which possibilities, expectations, benefits, and hopesor fear and anxieties - are projected. People trust the academic reputation of excellent universities or departments even if unfamiliar with any of the scholars working there. The symbolic meaning, reputation, and attractiveness of a university lie not only in its present merits and achievements but also in those of previous scholars no longer belonging to the institution's knowledge environment. In many university towns these collective memories and narratives are reinforced by regular selfreenactments (e.g., anniversary celebrations and graduation ceremonies) or an iconography of the urban space. Plaques on buildings, museums, and memorials constantly remind people of past achievements by famous scientists or of important local events in the history of science. An awareness of the city's iconography and recurring contact with places important in the history of science can instill in scholars and students an emotional bond ${ }^{3}$ and can support personal identification with their university. A university is a junction or intersection where the career paths of academics of various disciplines, generations, and provenances meet, where scholars communicate and (it is hoped) interact with each other for a certain period. ${ }^{4}$ Universities and other research institutions are not simply locations but social spaces, epistemic venues, nodes of scientific discourse, enablers or impediments of actions, and carriers of reputation.

In summary, recent theoretical and methodological trends in a number of scientific disciplines underline the importance of environments for action, learning processes, and problem-solving. This chapter focuses on the role of knowledge environments at universities and their impact on research processes and academic careers. I focus on five questions: What does the term knowledge environment mean? Which components constitute a local knowledge environment? In what way can a local knowledge environment affect goals, decisions, learning, research processes, and the careers of academics? Which theoretical concepts can contribute to the understanding of the interaction between knowledge environment and individual

\footnotetext{
${ }^{2}$ All translations are my own unless otherwise stated.

3“Any kind of learning is connected with some tradition," and names of scholars, places, and scientific practices "already suffice to form a collective bond" (Fleck, 1935/1979, p. 52).

${ }^{4}$ Mager $(2012$, pp. 251, 253) gives an example of the representation of career paths in a time-space model.
} 
scholar? How can the consequences of a knowledge environment be verified? The main goals of this chapter are to shed light on possible research agendas about knowledge environments and to discuss some of the methodological and theoretical issues connected with knowledge environments. ${ }^{5}$

\section{What Is a Knowledge Environment and Which Caveats Should Be Considered?}

\section{Research Needs Specific Environments}

Scholars depend on research infrastructure, financial resources, face-to-face contacts with distinguished members of various disciplines, critique and support of peers, and experienced key persons. There is no doubt that cognition, aspirations, motivations, and emotions of scholars can be influenced by the ambience in which they act. New scientific results have to be accepted and legitimated by other scholars. Local knowledge environments can enthuse, support, or frustrate scholars. In each discipline, departments, faculties, and universities differ in resource endowment, the availability of sophisticated and expensive research infrastructure, ${ }^{6}$ the career opportunities they open up to academics, and the extent to which their scholars are integrated into important national and international scientific networks.

The history of science is rich in examples of creative scholars and innovative research projects having met with rejection, incomprehension, neglect, and hostility at particular universities. However, there are also many examples of scholars of slowly changing or disrupting the knowledge environment of their place of work by altering the rules, conventions, and style of leadership, by upgrading the resources of their institution, and by hiring new academic staff. A knowledge environment is never stable; it is constantly in motion.

Sociology of knowledge, environmental psychology, geography of science, creativity studies, institutional theory, research on organizational behavior, and other fields have studied a great number of particular parameters, conditions, and structures affecting learning and research. Scholars studying knowledge environments build on this kind of research, but they are more interested in the connectivity, interdependencies, interrelations, and interactions of relevant variables at a certain place or environment. These academics focus especially on the scientific outcomes of different environments.

In summary, a university's knowledge environment is definable as the result of systemic interdependencies and causal interactions of personal, financial, material and nonmaterial resources relevant to the generation, diffusion, and application of

\footnotetext{
${ }^{5}$ See Meusburger and Schuch $(2010,2012)$ for empirical studies.

${ }^{6}$ Research infrastructure is more than technical equipment. It also encompasses privileged access to documents, unpublished census data, and private archives.
} 
scientific knowledge at a specific place or environment. A knowledge environment is a multiscale phenomenon. From the perspective of an individual scholar, it is a subject-centered space of cognition, interaction, and learning. From a systemic perspective, analysis focuses on mutual interdependencies of processes and parameters that influence the production of knowledge. Parameters effective at the local, regional, national, and global level intermingle with each other at a specific place in a particular way and evolve into an inimitable local knowledge environment. Saying that the knowledge environment of a university is a case sui generis does not preclude the generalizability of specific processes and interrelations characterizing knowledge environments. As Mayntz (2002) put it,

systemic interdependences are about mutual dependence and influence in the relations between different simultaneous processes or between different institutions. The discrete processes or institutions are parametrically linked with each other as it were; that is, they can reciprocally change important basic conditions for each other. (p. 33)

Because creativity is domain-specific, agents working in different domains (e.g., science, humanities, arts, industry, and financial services) need different knowledge environments. Some scientific disciplines depend more on research infrastructure and financial resources than others do. Theoretical physicists, for instance, are less place-dependent in their research than experimental physicists, who may find only three locations in Europe where they can conduct their costly experiments.

The intensity to which scholars need or depend on their knowledge environment also varies over time. In some phases of their research projects, scholars seek intense interaction with their environment, have many face-to-face contacts with experts of other fields, engage as many researchers as possible in multifaceted negotiations, depend on support and critique from peers, "borrow metaphors and notations from epistemic sources as distant as possible to maximize innovative variance" (Fiedler, 2004, p. 126), and seek both controversy with epistemic opponents and inspiration through serendipitous interaction with scholars from other research fields. In other phases scholars try to avoid the noise of their environment, retreating to concentrate on their manuscripts without interference. These processes of opening and narrowing the areas of contact are similar to what Kelly (1955/1991) called the "Creativity Cycle": "The Creativity Cycle is one which starts with loosened construction and terminates with tightened and validated construction" (Vol. 2, p. 7). As Fiedler (2004) explains, a creativity cycle

encompasses two stages, loosening and tightening. By analogy to evolution theory, loosening corresponds to the production of random variation ..., whereas tightening corresponds to a subsequent selection stage that serves to separate the strong and weak products of the preceding loosening stage. (p. 124) 


\section{Research on Knowledge Environments of Universities Should Address Various Caveats}

First, a knowledge environment should not be thought of as an independent variable that directly influences all actors through direct cause and effect (if A, then B). It is rather a locally available potential or local offer of resources, opportunities, incentives, challenges, stimulations, and support networks. What makes a location attractive is its potential for high-level interactions, its possible or imagined advantages, not just the realized ones. This local potential can be used, ignored, or rejected by scholars working at the relevant place. A knowledge environment can operate as it should only if the actors involved appropriate and use the local resources, take advantage of the opportunities, understand and adopt the available knowledge, use the available research infrastructure proficiently, and interact with each other appropriately. Only interested, competent, and talented individuals will be able to take full advantage of a given knowledge environment. ${ }^{7}$ A knowledge environment does not come out of the blue; it is constantly molded and remolded by scholars and other people responsible for a research institution.

Second, the outcomes of human interactions and experiences in life are always indeterminate. No one can predict the results of learning, appropriation, and interaction, the ways in which the relationships between individual scholars of different age groups and disciplines will develop, or whether and how often the local potential for integrating diverse viewpoints and knowledge bases will be activated. It is relatively easy to analyze some of the preconditions for scientific creativity (e.g., financial, personal, and material resources) by multivariate methods, ${ }^{8}$ but a knowledge environment's significance and effect in a given period are explicable only ex post-after events have taken place, after the scientific careers and research results associated with a place, territory, or environment have become evident.

Third, students of knowledge environments must cope with the contradiction that knowledge environments are both volatile and remarkably robust. Many important elements of a knowledge environment are fleeting - eminent scholars and talented students come and go, research questions and methods change, the creativity of scholars varies over time, financial resources (especially external funding) fluctuate, and internal conflicts or imprudent appointments of professors may detract from a department's scientific achievements and reputation. Conversely, the scientific quality and reputation of an institution's knowledge environment in many cases show a remarkable robustness over time. Excluding wars (see Meusburger, 2012a, pp. 19-20, 22; Neumaier, 2012; Rotzoll, 2012, and the chapter by Hotson and Meusburger \& Próbald in this volume) and other political disasters (see Mußgnug, 2012), many countries have a remarkably stable hierarchy of universities as self-

\footnotetext{
${ }^{7}$ This experience is one of the main reasons why recruitment processes of scholars are crucial for the quality of a knowledge environment.

${ }^{8}$ Contextual studies of knowledge environments do not replace multivariate analyses but rather contribute additional benefits and new insights.
} 
organizing systems. The hierarchy of universities admits of some upward and downward mobility, but it is rare that a university soars from the lowest to the top rank of a nation's university hierarchy or plummets from the top to the bottom. This persistence, or "dynamic robustness," 9 is usually due to universities' differential ability to regulate themselves and adapt to new challenges, the so-called Matthew effect ("the more you have, the more you get"), and other factors contributing to a university's scientific attractiveness.

Fourth, it is necessary to take the time dimension into account. Short-term evaluations of a knowledge environment may be quite biased. With hindsight, most people judge persons, situations, processes, and environments differently than immediately after a certain event has occurred. A senior professor might evaluate the knowledge environment of his or her institution differently than a doctoral student does. A knowledge environment is characterized by multiple realities (Graumann, 1983).

\section{Of What Components Does a Local Knowledge Environment Consist?}

\section{Capacities, Characteristics, and Behavior of Persons Significantly Involved in the Activities of a Scientific Institution}

The most important element of a knowledge environment at a given place are its human beings (e.g., scholars, students, technical, and administrative staff) with their cognitive capacities, competencies, skills, experiences, scientific reputation, personal networks, emotions, and manner of interacting with other people. It depends mainly on these stakeholders how the other elements of a knowledge environment (including resources, infrastructure, organizational culture, and scientific reputation) develop and interrelate with each other.

The key quality of a knowledge environment is its power to attract internationally renowned scholars and highly talented students. To become and remain attractive and internationally competitive, a university's knowledge environment must continually be replenished by the best available candidates bringing in new ideas, new research questions, innovative scientific methods, new constructive criticism on existing research, new bodies of knowledge, professional experience with other settings and research cultures, high quality standards in teaching and research, international personal networks, high social competencies, and appropriate professional value systems. The input of newly appointed scholars may influence the dynamics of the university's capacity of self-regulation and the range of international networks and communication spaces. Scholars socialized in other knowledge environments may question or subtly change some of the prevailing institutional logics at

\footnotetext{
${ }^{9}$ I borrow this term from Robert Panitz (Department of Geography, Heidelberg University).
} 
their new place of work. Scholars criticizing mainstream theoretical discussions in their discipline will have an interest in counterhegemonic practices (see Clegg, 2010, p. 8), and some of them will even be able to affect governance structures in important ways (Dacin, Goodstein, \& Scott, 2002, pp. 51-52).

There are several key questions for the success of this process of continuous intellectual renewal: According to which quality standards are academics appointed? How transparent are the recruitment processes? What personal, financial, and material resources is a university able to offer to its newly appointed scholars? Which levels of scholars is a university able to attract? Some universities will be more successful than others in the competition to hire the best candidates.

Intellectual renewal comes about not only through the appointment of new scientists but also through what is known as circular mobility (for details see Jöns, $2003,2007,2008,2009,2017$ ), such as brief periods of study abroad, the invitation of visiting scholars, scientific cooperation with other institutions, and other ways of exchanging and testing new knowledge (e.g., participation in conferences). Mobility is equivalent to gathering experience in different knowledge environments, tackling new challenges, and familiarizing oneself with issues and methods one has not encountered at previous places of work. Mobility can trigger new ways of learning and thinking, enrich a scholar's capacities, and bring about new cooperation in the world of science.

\section{Financial and Material Resources}

Whether distinguished scholars and talented students are attracted to a given university or not partly depends on its basic material wherewithal—its financial strength and the quality of its research infrastructure (libraries, laboratories, computing centers, archives, and other rare or expensive research facilities). Many innovative research questions can be studied empirically only if the latest research equipment and analytical methods are on hand or if a scholar gains access to hitherto unused data sources or archives. The more expensive such research infrastructure is, the fewer universities there are that can acquire it.

To attract the famous chemist Robert Bunsen (1811-1899) to Heidelberg University in 1852, the government of the Grand Duchy of Baden funded a state-of-theart chemistry laboratory building, in those days the most modern in the world. In the second half of nineteenth century, the Grand Duchy of Baden spent about $4 \%$ of its state budget on its two universities and a technical college, and its per capita expenditures on universities exceeded those of any other German state (Pfetsch, 1974). Robert Bunsen was a prime reason why other exceptional scientists, including Hermann Helmholtz (1821-1894) and Robert Kirchhoff (1824-1887) joined Heidelberg University and created a research center of worldwide reputation (for details see Eckart, Hübner, \& Nawa, 2012; Hübner, 2010; Meusburger, 2012a, b, 
Meusburger \& Schuch, 2010). Because the government provided Bunsen with eight assistants ${ }^{10}$ (most of his colleagues had only two), and because he generously allowed them to pursue their own research interests, his department pioneered a unique variety of new research fields that made Heidelberg the power center of chemistry for some decades.

This example confirms that financial and material resources should not be isolated from the scientific achievements and reputation of a university's scientists. In most countries research money does not flow automatically. It must be acquired by scholars in keen national and international competition or negotiated during an appointment process. The fact that only a small share of distinguished scientists will be successful in these hard competitions for research grants and expensive research equipment feeds the ascending spiral of attractiveness and the effect of "the more you have, the more you get." This is one of the main reasons why the university system has a relatively stable hierarchic structure-at both the national and global levels.

Empirical data from almost every country documents that most research funding goes to only a few universities. In Germany, for instance, the 40 universities $(9.4 \%$ of all the country's universities) that were most successful at securing external funds from the German Research Foundation (DFG) received $86.6 \%$ of all DFG funding from 2011 through 2013 (Deutsche Forschungsgemeinschaft, 2015, p. 60). Of the approximately 420 German universities (average from 2011 through 2013), 230 still did not have the right to award doctorates in 2013, which of course has a negative effect on research performance (Deutsche Forschungsgemeinschaft, 2015, p. 33). Expensive new research infrastructure is usually first introduced at leading research universities, so these repeatedly gain advantage, enhancing the Matthew effect.

\section{Organizational Structures, Institutional Rules and Logics, and Scientific Cultures}

Although above-average financial and material endowment is crucial to a university's attractiveness, it by no means guarantees excellent scholarship. Organizational structures, institutional logics, scientific or epistemic ${ }^{11}$ cultures, and other immaterial factors influencing communication, interaction, practices, and scientific ethics at a scientific institution or among the members of a research group can have great impact on the success of research processes and on the academic careers of junior scientists.

Evaluation of scientific cultures and the organizational behavior of departments or universities raises some decisive questions: What kind of positive and negative role models exist in a department or faculty and how influential are they? What kind

\footnotetext{
${ }^{10}$ Today they would be called assistant professors or lecturers.

${ }^{11}$ For details see Knorr-Cetina (1999).
} 
of motivation, intellectual encouragement, and emotional and financial support do doctoral students and junior scientists receive in their department? How do research groups cope with dynamic complexity and uncertainty? What are the quality standards for research, teaching, and administration ${ }^{12}$ What kind of publication culture prevails in a department or faculty? What kind of assessment tools are used to measure the quality and impact of research $?^{13}$ Is research evaluation institutionalized by a standard protocolization of assessments (see overview by Wouters \& Costas, 2012) or is there respect for diversity of assessment tools? How do key decisions on structural changes, resource distribution, and new research fields come about within a department, faculty, or university, and what criteria apply? How are conflicts of interests solved? To what extent do established scholars exploit the research of their doctoral students and junior scientists? How great is the scientific autonomy of doctoral students and junior scientists? To what extent are they free to follow their own research interests and to choose their theoretical concepts and methodologies? ${ }^{14}$ The influence of assessment practices on publication strategies can hardly be overestimated. In some departments, unfortunately, publication is tied less to scientific principles than to the number of points it will bring the authors for their next assessment or promotion.

Studies in business administration, organizational and institutional theory, and complex problem-solving yield interesting findings about the impact of organizational climate and institutional expectations on performance in industrial firms and the service industry. However, the decisive question is the extent to which these findings can be transferred to basic research of top universities-especially in the early phases of a creative process. Universities should not be confounded with industrial companies. They cannot be organized, coordinated, and evaluated like a company manufacturing sausages (for details see Beck, 2005, pp. 99-100; Weichhart, 2012a, pp. 14-15). The problems with which universities must cope are much more ill defined ${ }^{15}$ than those confronting industrial firms. The issues that

\footnotetext{
${ }^{12}$ Weichhart's (2012b) sarcastic essay lists several shortcomings frequently observable in assessment practices focusing on formal criteria rather than the innovativeness, originality, and quality of research.

${ }^{13}$ In digital societies the number of assessment practices and citation and impact measures has increased dramatically despite the highly problematic nature of most of these indices from a methodological and statistical point of view (for details see Franzen, 2011, 2015; Wouters \& Costas, 2012).

${ }^{14}$ The last three questions of this paragraph will be valued differently in specific research fields. What is everyday practice in department (or discipline) A will be frowned upon in department (or discipline) B. The key questions are which of the mentioned organizational cultures, assessment practices, and types of scientific relationships expand the latitude that junior scientists have in order to develop their creativity and pursue a successful academic career and which of those tend to maximize the benefits of senior scientists instead.

15“"Well-defined problems have a clear set of means for reaching a precisely described goal state.... Ill-defined problems have no clear problem definition, their goal state is not defined clearly, and the means of moving towards the (diffusely described) goal state are not clear" (Dörner \& Funke, 2017, p. 1).
} 
universities grapple with incorporate all the typical attributes of complex systems described in detail by Dörner and Funke (2017):

According to Funke (2012), the typical attributes of complex systems are (a) complexity of the problem situation which is usually represented by the sheer number of involved variables; (b) connectivity and mutual dependencies between involved variables; (c) dynamics of the situation, which reflects the role of time and developments within a system; (d) intransparency (in part or full) about the involved variables and their current values; and (e) polytely (Greek term for "many goals"), representing goal conflicts on different levels of analysis. (p. 2)

The university is a complex, dynamic system characterized by intransparency, a high degree of self-governance of its single elements (e.g., departments and research groups), and a vast multiplicity of goals. ${ }^{16}$ Unlike top managers of industrial firms or public administration, who set forth clearly defined objectives to all its actors (at least for specified period), a rector, dean, or the administration of a university cannot prescribe the research topics its scholars are to study, which methods they are to use, or which cooperations and networks they have to join. Basically, each scholar can follow his or her own objectives or, in commercial terms, can pursue his or her own product and marketing as desired. Scholars often try to solve on their own the complex problems that they have found or created and that were not known before (for details about problem-solving, see Dörner, 1996; Dörner \& Funke, 2017; Funke, 2012). ${ }^{17}$

Croissant (chapter in this volume) draws attention to a famous dictum of Albert Einstein: If we knew what we were doing, it wouldn't be research. This statement applies especially to high-level basic research in the first phase of the innovation S-curve-where pioneering scientists study important topics only very few people, if any, have tackled. This kind of pioneering basic research must be distinguished from applied research, which has explicit goals, and from basic research in late phases of the S-curve on topics that have been on the table for many years and are already being tackled by large clusters of scientists all over the world. ${ }^{18}$

Goal-oriented, applied research can be managed and organized to a greater extent than pioneering, high-level basic research, which involves much more uncertainty (e.g., uncontrollable conditions and unexpected events). The problematic term

\footnotetext{
${ }^{16}$ University actors pursue many different, sometimes quite contradictory goals. The problemsolver must therefore set priorities and make compromises.

${ }^{17}$ The problems to be solved are "self-created" because they would not exist if it were not for the scientific curiosity of researchers.

${ }^{18}$ Distinguished research universities have all types of basic and applied research. Universities ranking lower in the national hierarchy predominantly conduct applied research or basic research in a late phase of the S-curve.
} 
"organized creativity" 19 should be used only, if at all, for research conducted in the late phases of the S-curve. Pioneering, high-level basic research in the first phase of the S-curve is difficult to manage or coordinate because most upcoming research questions, methodological problems, and outcomes of research processes are not yet foreseeable. Applied researchers at least know their main research questions. In high-level basic research, it is possible to organize financial resources, research infrastructure, and safety regulations for some of the work processes but not the generation of new ideas, the outcome of interactions, or the behavior and scientific ethics of supervisors. $^{20}$

The key issue for creating an optimal research culture is to find a balance between two positions that initially seem to contradict each other. On the one hand, certain institutional rules, guidelines, best practices, and evaluation mechanisms are indispensable for enforcing and sustaining high-quality research and teaching and for avoiding misbehavior and unethical practices. On the other hand, creative scholars need a great deal of academic freedom and personal autonomy to achieve outstanding scientific achievements. Without this freedom and autonomy, without being allowed phases of search and orientation that may fail (Weichhart, 2012a, p. 15), they will not have the courage to abandon outmoded thought structures; to forsake beloved scientific routines; or to criticize departmentally esteemed, but superficial, assessment tools $^{21}$ that may even dominate the core of their discipline. Creative scholars stand out not just by having new, original, and valuable research results but also by showing the courage to break through institutional constraints and

\footnotetext{
${ }^{19}$ Unfortunately, some authors in business studies, economics, and urban and economic geography do not use the term creative as it has been defined in the field of creativity studies (Boden, 1994, 2004). Florida $(2002,2005)$ has introduced a rather colloquial meaning of the term, but it has nothing to with the scientific definition of creativity as developed in psychology. Creativity research distinguishes between at least two types of creativity: psychological and historical. Psychological creativity is ubiquitous. A three-year-old child who discovers something new and valuable for himor herself is creative. Every profession imaginable is at least occasionally creative in the psychological sense. Terms such as creative industry or creative class (Florida, 2002, 2005) are therefore contradictions in themselves. Whether a person, process, or product is historically creative can be judged only after the results have become apparent.

${ }^{20}$ Supervisors who are convinced that they are entitled to exploit the research results of their doctoral students can scarcely be organized in a way that changes their behavior. Established scientists who have neglected important research in neighboring disciplines or in languages than other English are hard to convince that they should change their gridlocked behavior.

${ }^{21}$ Wouters and Costas (2012) discuss the limitations of established and emerging impact metrics and the interplay of technologies of narcissism (self-assessment), information-filtering, and technologies of control that shape science in the digital age (see also Franzen, 2011, 2015, 2017; Meyer \& Gupta, 1994). In digital societies the number of companies offering citation and impact measures (F1000, PaperCritic, Google Scholar, Google Citations, Arnetminer, JISC Open Citations, Mendeley, CiteUlike, Zotero, Scopus, Readermeter, ScienceCard, and many others) has increased dramatically, although most of these indices are extremely problematic from a methodological and statistical standpoint. Such organizations are booming because they oblige both the control mania of institutions and scholars' greed for reputation and status (for details see Franzen, 2011, 2015; Wouters \& Costas, 2012).
} 
expectations of their social environment. They do so not from ignorance of the rules or leading paradigms but rather from their personal experience that those rules and paradigms are no longer adequate (helpful) in their field and now only stifle creativity or obstruct efforts to advance scientific knowledge and insight. Being creative thus also means having courage to resist the mainstream in their discipline or least being able to endure for a while without the applause of colleagues.

\section{External Factors of Influence}

Universities have never been able to withdraw from the influence of national and local politics. Private universities may be less affected by the science policy of a state than public universities are, but no university is able to remain unaffected by politics. In some countries the decision-making community tends to distribute funding for public universities according to criteria shaped by industrial policy rather than science. Politicians often lack the willingness to acknowledge the difference in quality between public universities and to take account of it when allocating financial resources. Many times, the bargaining process in governments seems to be guided by the motto, "If your region receives money, then my region has to get some, too." This approach is defended with the argument that the allocation of research funding is intended to offset disequilibria in regional development. Such regional policy has had little success and has hurt the good universities in international competition for scientific standing.

Equally important are the attitudes of the local population (and their politicians) toward science in general and toward their university in particular, local principles of urban development planning, potential expansion of an existing campus, a university's relations to the region's economy, the support of a university by philanthropists, and many other factors. ${ }^{22}$

Paradoxically, the knowledge society of the twenty-first century is characterized by the simultaneous and unprecedented increase in both scientific knowledge and ignorance (not-knowing). The gaps between experts and nonexperts are widening dramatically. Leading scientific institutions must cope with more ignorance and lack of understanding from some local and national politicians than ever before. In the twenty-first century presidents of important nations deny climate change, and vice presidents deny evolution and adhere to creationism. In Heidelberg some politicians of the town council (e.g., members of the leftist party Bunte Linke) maintain that scientists no longer need face-to-face contacts because they communicate primarily via the Internet. Scientific institutions would, therefore, no longer need proximity to each other; they could be localized anywhere. The attitude of local politics and urban

\footnotetext{
${ }^{22}$ This volume's chapters by den Heijer and Curvelo Magdaniel; Etzkowitz; Goddard; Heffernan and Jöns; and Zillich focus on some of these external factors, so it is unnecessary to repeat their arguments here.
} 
planning toward the needs of scientific institutions will become an increasingly important locational factor.

Another important location factor for universities are the activities of philanthropists in their region. According to Glückler and Ries (2012), Heidelberg University has long enjoyed privileged status in this respect because most of the local philanthropists identify with the oldest university in Germany even if they are not Heidelberg University alumni.

Almost half of all the grants [of philanthropists and local foundations] went straight into
academia and research (48\%) and another $41 \%$ favoured charity and society. The area of
culture and arts received no more than $11 \%$, respectively. This distribution of philanthropy
contradicts with general trends in the non-profit sector. At the national and European level
philanthropic investments largely flow into charitable social welfare projects. Only $13 \%$ of
all foundations in Germany declare science and academia as their primary target group
(Bundesverband Deutscher Stiftungen, 2010). And according to a recent survey on
European foundations in seven EU member states, only 3\% of all grants benefit the realm
of academia (European Foundation Centre, 2008). (Glückler \& Ries, 2012, p. 522)

These statements are additional evidence that place matters and that the identification of high-level local decision-makers with their university is a valuable asset.

\section{How Can a Knowledge Environment Affect Learning and Research Processes at a Given Place?}

\section{Universities Offer Unequal Learning and Research Opportunities}

In principle, cognition and thought processes of individuals can take place everywhere. Why should a situation, setting, place, venue, spatial configuration, or environment affect cognition, motivation, learning, and research processes? The answer is relatively simple. Different places and work environments open different opportunities to learn, different possibilities for face-to-face contact, different resources for research and access to different networks, and different incentives and obstacles enabling or impeding specific learning processes and actions.

Universities vary in academic reputation, scientific achievements, the resources they offer, domain-specific authority, innovativeness, and the attractiveness of their location. Different departments (faculties, universities) consist of different research cultures. They train students in different fields and methodologies, exert different amounts of control, allow different degrees of autonomy, and present different truths. Some departments belong to the innovators or early adopters of a new research field, theory, or methodology; others, to the late adopters. Some of these actors do not even realize that they have overlooked important developments in their field of research.

At the top of the hierarchy are research universities and nonuniversity research institutions that enjoy an excellent international scientific reputation, have extensive 
research funds, and can attract the best talent worldwide. At the base are universities that have little or no research funding, are unable to engage scientifically renowned scholars, are not entitled to submit applications to important research foundations, have no right to award doctorates, primarily teach, and draw a large percentage of their students from a relatively small catchment area. The higher the scientific reputation of a university, the more it acts as a magnet attracting the best candidates available and the more impressive are its global networks and recruitment areas. Highly successful scholars can choose between many job opportunities ${ }^{23}$ and vote with their feet.

Do outstanding candidates accept a university's call because the university has a sterling scientific reputation and provides an attractive research infrastructure? Or does the university have a high reputation and an attractive research infrastructure because it has had outstanding success for decades in appointing outstanding scholars? These questions indicate that two intertwined mechanisms are responsible for the quality and development of a knowledge environment. If a faculty or university is capable of recognizing ${ }^{24}$ and attracting outstanding scholars over a lengthy period, then the probability is very high that these scholars will create the resources, incentives, and research cultures necessary for an attractive knowledge environment and an upward spiral of attractiveness. If many search and appointment procedures fail to produce the desired positive results, then the knowledge environment of that institution will deteriorate. Mediocre scholars will later recruit mediocre colleagues. If this downward spiral continues for long and falls below a certain level, the university will no longer receive applications from promising applicants.

\section{Environment Related Mechanisms and Processes that Influence Learning and Research?}

"Introduction to a field of knowledge is a kind of initiation that is performed by others" (Fleck, 1935/1979, p. 96). A teacher-student relationship is characterized by asymmetries of power, experience, and knowledge, but it is also subject to cultural influences. ${ }^{25}$ Many doctoral students depend on financial resources and research

\footnotetext{
${ }^{23}$ This regularity does not apply to small disciplines (e.g., Assyriology, Medieval Latin) that have a notably restricted job market. Another consideration is the market cycles of disciplines that influence the number of appointments at universities.

${ }^{24}$ Daily experience and the history of science in universities prove that nowhere near all recruitment committees, faculties, and senates of universities are capable of detecting which of the many candidates are the most talented, competent, and promising. Committees and university presidents relying on superficial and questionable impact factors (e.g., the $\mathrm{H}$-factor) have made terrible mistakes that have brought disaster upon the departments involved (see Weichhart, 2012a).

${ }^{25}$ It is quite interesting that in German-speaking countries the person who oversees or guides a graduate student's work on a doctoral dissertation is known as a doctor father (Doktorvater) or doctor mother (Doktormutter), whereas the common term is supervisor in Anglo-Saxon countries.
} 
infrastructure to which senior scientists give them access. Doctoral students and junior scientists are subject to a certain measure of disciplinary control and are influenced by what the prominent members of their department or discipline view as established knowledge, appropriate methods acceptable experiments, and desirable forms of publication.

Which elements and processes of the environment are able to affect learning processes? Supervisors, reviewers, role models, critical audiences, institutional regulations, informal expectations of their social environment, and a multitude of other factors shape the goals, research interests, and fields of interaction of young scholars. "Actors perceive the meaning of institutions and infuse their actions with meaning based upon these perceptions" (Dacin et al. 2002, p. 47). Very few prospective scientists can ignore a dominant paradigm ${ }^{26}$ or thought style and the expectations communicated in their social environment, at least not in the first years of their academic career. Therefore, students and young scholars operate in an environment of "preorganized knowledge" (Knoblauch, 1995, p. 15), they are being socialized in epistemic and scientific communities and specific "thought styles" (as defined by Fleck, 1935/1979; Trenn \& Merton, 1979).

A thought style functions by constraining, inhibiting, and determining the way of thinking.
Under the influence of a thought style, one cannot think in any other way. It also excludes
alternative modes of perception. Accordingly, no proper communication can arise between
different thought styles. A thought style functions at such a fundamental level that the
individual seems generally unaware of it. It exerts a compulsive force upon his thinking, so
that he normally remains unconscious both of the thought style as such and of its
constraining character. Yet such a style can be revealed in practice by an examination of
how it is applied. The existence of stable thought collectives suggests the presence of a rather
permanent thought style. (Trenn \& Merton, 1979, p. 159)

According to Kuhn (1962), the process by which scientific disciplines change and develop is not characterized by a cumulation of knowledge but rather by fundamental crises and discontinuities, each of which eventually causes one paradigm to be replaced by another. There is broad agreement today, however, that several paradigms can coexist and compete with each other in a given period (for details see Schurz, 1998; Weichhart, 2012b, pp. 54-55).

Particular research groups and subdisciplines are repeatedly marked by the emergence of dogmatic convictions indisputable and seemingly unassailable among their adherents but sharply criticized by proponents of other paradigms. Paradigms thus not only reflect developmental processes of sciences, they also have great societal significance (Weichart, 2012b, p. 56). They promote cohesion and loyalty within research groups and can simultaneously exclude representatives of other paradigms.

\footnotetext{
${ }^{26} \mathrm{~A}$ paradigm is understood to mean a research-guiding perspective or viewpoint on which consensus builds for a given period and group of scholars. Paradigms offer scientific conceptions of the world that facilitate the formulation of and solution to problems in specific ways that the experts accept without question (Weichhart, 2012b, p. 54).
} 
Established scientists who are convinced that their theoretical and methodological approaches are superior to those of others tend to exert a measure of control within their research group or intellectual community. Within a thought collective (e.g., among the members of a research group) doctoral students and junior scientists repeatedly confirm that their group is on the right track and will be successful with its research. "A special feeling of dependence therefore dominates all communication of thought within a collective" (Fleck, 1935/1979, p. 106).

Between two members of the same thought collective on the same mental level, there is always a certain solidarity of thought in the service of a super-individual idea which causes both intellectual interdependence and a shared mood between the two individuals. (p. 51)

Intellectual solidarity and mutual confirmation reduce uncertainty about the value of one's research, but they also reduce the willingness of self-criticism and the ability to learn.

\title{
The Significance of Social Spaces
}

Livingstone (1995, 2000, 2002, 2003, 2005, 2010) has called attention to the critical significance of social spaces - especially spaces of speech and spaces of readingfor the generation and distribution of new research results. "[S]cience is made and remade by how it is talked about" (Livingstone, 2010, p. 18).

\begin{abstract}
What can and cannot be said in particular venues, how things are said, and the way they are heard are all implicated in the production of knowledge spaces. In different arenas there are protocols for speech management; there are subjects that are trendy and subjects that are taboo. In public spaces and in camera, in formal gatherings and in private salons, in conferences and consultations, in courtrooms and churches, in clinics and clubs-in all these venues different things are speakable (and unspeakable) about scientific claims. In every case the setting sets limits on what can be spoken; the social space conditions what is heard. . . [T]he control of speech space is intimately connected with the maintenance of identity. Spaces of speech, of course, are also spaces of silence. There are always voices that are absent, or are not allowed to speak, or are denied access. In colonial societies, as Scott (1985) powerfully reminds his readers, the oppressed can rarely let their voices be heard. No doubt for different reasons, but with not dissimilar effects, those people marginalized in scientific debates find their voices unwelcome in science's privileged sites. (p. 16)
\end{abstract}

A textbook example often cited in science studies (e.g., Livingstone, 2003, 2010) concerns the reception of Darwin's main work, On the Origin of Species (1859). The book was interpreted differently in Belfast than in Edinburgh. In Charleston it was seen as an argument for racism; in Auckland, as one against it. "Darwinian language was embraced to a much greater degree in Canada than it was in Russia" (Livingstone, 2010, p. 10). "In Boston, the students of Louis Agassiz could talk about the new Darwinian theory only in secrecy for fear of their teacher's ire" (p. 17). Meusburger (2012b) has continued the narrative: 
Immediately after the book was published, the Heidelberg paleontologist Heinrich Georg Bronn (1800-1862), who was also the prorector of Heidelberg University at the time, translated On the Origin of Species into German, a version that appeared in 1860. Bronn enjoyed a good personal relationship with Darwin. Their bond, though, did not keep Bronn from reading Darwin's work very selectively and incorporating elements of his own perspectives into the translation. (p. 16)

Darwin's breakthrough in German-speaking countries was accomplished by Haeckel (1866, especially 1868). In a lecture entitled "Darwin's Theory of Evolution" and delivered in Stettin on September 19, 1863, at the meeting of the Society of German Naturalists and Physicians (founded in 1822), Haeckel made it clear that science was undergoing a profound change of paradigm.

The institutional, cultural, and social context in which a young person studies or a young scientist does research and teaches can be elemental in determining the research topics they will find of interest, the methodological skills they will acquire, the scientific networks they are able to join, the kind of critique and support they will encounter, and the interesting, unsolved problems they will notice. The knowledge environment of a university can have a bearing on whether and how soon new scientific concepts, practices, or technical innovations are accepted and acted upon and whether it is possible to discuss contested ideas, conduct expensive experiments, become part of important international networks, hear promptly of crucial developments, meet with agreement or criticism upon airing new ideas, or get away with straying from rigid regulations of a discipline's gatekeepers (Meusburger, 2012b, pp. 12-14).

Support from key figures in their discipline will affect the initiative and resilience of these young academics and will shape the subsequent perception they have of their roles as lecturers or researchers (Meusburger, 2012b, p. 14). Prominent scholars indisputably play a major part in shaping the development and careers of talented students. The history of science is replete with evidence of how a head start translates into a crucial advantage in a scholar's later career and creates important path dependencies. Just as certain time periods offer unique windows of opportunities, certain places and knowledge environments engender superior learning opportunities and role models, specific value systems, specific challenges, and outstanding prospects for professional careers.

Daily interaction with positive (or negative) role models and personal relationships have lost none of their significance in the age of the internet. On the contrary, the overwhelming flood of information and questionable publications have only increased the importance of face-to-face contacts with leading thinkers from the relevant disciplines (Meusburger, 2012b, p. 14). 


\section{Theoretical Concepts Contributing to the Understanding of How Knowledge Environments Function}

\section{"Knowledge Travels in a Selective Way"}

The functioning of a knowledge environment depends, first, on the quality of the information exchange at the given place. This statement may seem trivial, but a local cluster of illustrious and globally networked scientists does not automatically equate with creative environments, knowledge exchange, scientific cooperation, or mutual inspiration across disciplines. Although proximity facilitates unplanned, spontaneous, face-to-face contact, it does not guarantee interaction and exchange of knowledge. Scientific insights and acquisition of scientific knowledge rely on dialogue, scholarly debate, and other forms of communication and interaction. What counts is whether and to what extent the scientists at a university interact and engage in crossdisciplinary discussion (Christmann, 2016; Keller, Knoblauch, \& Reichertz, 2013; Knoblauch, 2016) and how they manage their social relations in that environment. A knowledge environment does not emerge until the actors communicate and interact with each other; come to grips with the structural conditions, institutional regulations, and organizational cultures in which they find themselves; and prove themselves willing and able to activate the locally available potential.

The key words are not cluster or proximity but communicative interaction and ways to transcend the silo principle. The silo mentality is a condition or attitude marked by an absence of open and cross-disciplinary communication and a disinterest or unwillingness to learn from other disciplines and thought communities. ${ }^{27}$ It is combined with so-called boundary-work ${ }^{28}$ and the persistence of staunch commitments to retaining and preserving established scientific concepts and methods of one's own research field. The difficulties posed by knowledge exchange between scholars of different disciplines, thought communities, or languages are vastly underestimated. The exchange of information between sender and recipient must overcome a number of filters. Even if a piece of information is understood by the recipient and might be valuable for his or her research, it may be rejected for various-also unscientific_-reasons (see communication model in Meusburger, 2017, pp. 38-43).

International knowledge exchange, scientific cooperation, and scientific travel are influenced by even more factors than individual communication, including state

\footnotetext{
${ }^{27}$ In Frey and Iselin (2017) 71 authors discuss ideas and concepts used in (traditional) economics that need to be corrected or call for modification or elimination. Examples are the idea of homo oeconomicus, the way in which the term rationality is used, the assumed effect of prices on behavior, and the disregard of intrinsic motivation and job satisfaction. Most of this critiqueespecially of rationality and behavior-was formulated in social and behavioral science decades ago. From the perspective of science studies, the interesting question is why and how the silo mentality of economists was able to repel this critique from other disciplines for so many decades.

${ }^{28}$ Boundary-work is "a combination of rhetorical and social organizational devices to exclude some people and their knowledge claims from science" (Gieryn, 1983, p. 786).
} 
fellowships, selective international research cooperation, old colonial relations, the quality of diplomatic relations, political goals, and shared denominations (Ellis, 2017; Heffernan, 1994; Heffernan \& Jöns, 2013; Jöns, 2009, 2017; see also chapters by Hotson and Meusburger \& Probáld in this volume).

\section{Concepts Focusing on Structure, Agency, Interaction, and Interrelations}

This chapter is not the place to discuss and value all the theoretical concepts that can help answer the question of how knowledge environments function. A brief overview will have to suffice. The first group of approaches centers on structure and agency and on relations between environment and behavior, social relations, interactions, and networks of the scholars working at a given place. Focusing on these facets, researchers study the "dialectical interplay between ... actions (practices and structures), meanings, and actors" (Zilber, 2002, p. 235; emphasis in the original; see also Dacin et al., 2002, p. 48). The best known of these concepts are structuration theory (Giddens, 1979, 1984; Werlen, 1997a, 1997b, 2017), actor-network theory (Latour, 1987, 1999), communicative constructivism (Berger \& Luckmann, 1967; Christmann, 2016; Keller et al., 2013), environmental psychology (Clitheroe, Stokols, \& Zmuidzinas, 1998; Graumann, 1978; Kruse, Graumann, \& Lantermann, 1990), concepts of appropriation (Graumann, 1996, 2002a, 2002b, 2002c; Graumann \& Kruse, 2003), environmental phenomenology (Seamon, 1982, 1987), interaction analysis (Argyle, 1957, 1969, 1991; Scharpf, 2002), network analysis (for an overview see Glückler et al., 2017), and organizational and institutional theory (Lawrence et al., 2011; Mintzberg, 1979; Suddaby, 2010; Suddaby, Elsbach, Greenwood, Meyer, \& Zilber, 2010). However, each of these theories or concepts leads to only a partial understanding of how knowledge environments function; each has its specific strengths and shortcomings. Many of these studies remain abstract and are place-blind, that is, they ignore not only the historicity of places but also what Raffestin (1989) calls the geographicity of knowledge production. Moreover, they do little to address the question of why norms, conventions, mutual expectations, and institutional logics may vary in the spatial dimension and, especially, why their correlations with other variables differ according to types of environments.

This is evident in institutional theory, which provides "new understandings of the manner in which institutions are created, transformed, and extinguished and the way in which institutional processes interact to affect institutional change" (Dacin et al., 2002, p. 45).

The concept of institutional work insists on the need to consider the permanent recursive and dialectical interaction between agency and institutions. This invites researchers to not only account for the institutional embeddedness of actors but also for their capacity to reflect on this embeddedness, relate to their own self, and develop conscious intentionality. Agency is neither just an effect of the actors' institutional embeddedness nor isolated from this 
embeddedness. It is an ongoing activity whereby actors reflect on and strategically operate within the institutional context where they are embedded. (Lawrence et al., 2011, p. 55)

A major shortcoming of institutional theory is the fact that its macroperspectives largely exclude issues of power and dominance (see Hudson, Okhuysen, \& Creed, 2015; Willmott, 2015).

In most institutional theory, examination of the relatedness of knowledge and power is deemed to be largely irrelevant; the self-understanding of institutional theory as politically neutral is self-evident; and the silence of institutional theory on contentious issues, such as the institutionalization of domination, oppression, and exploitation in modern work organizations, passes unnoticed. (Willmott, 2015, p. 106)

\section{Theoretical Concepts Focusing on Life Worlds and Holistic Interpretations}

Because the numerous components of a knowledge environment are strongly interwoven and interconnected, a knowledge environment is more than the sum of its single elements. Studying venues, environments, and social spaces of academic knowledge generation opens new horizons for explaining interrelations and path dependencies of academic careers and academic achievements.

Given the complexity and historicity entailed, the students of knowledge environments are less concerned with the discovery of causalities in the sense of universal laws than with the causal reconstruction of the network of interactions (see Mayntz, 2002, p. 22). The main interest lies in describing and interpreting a system's functionality and in identifying the "normative epistemological and discursive conditions" (Welskopp, 2002, p. 78) under which scientific achievement was scored. What is sought in the empirical analysis of social macrophenomena-such as knowledge environments-is

not abstraction and maximal simplification but rather specification and adequate complexity of the explanation. . . . Causal reconstruction is not about seeking statistical relations between variables but rather about explaining the macrophenomenon by identifying the processes and interdependencies involved in its having arisen. (Mayntz, 2002, p. 13)

Phenomenological approaches hold that cognitive processes should be thought of holistically and that one cannot describe place experience, knowledge environments, or life worlds by precisely dissecting them into constituent parts and then quantitatively measuring and modeling the significance of the discrete variables.

Gestalt psychology views perception and other mental processes as holistic rather than atomistic in nature. That is, complex perceptual and cognitive patterns are grasped in their entirety as integral wholes (gestalts), rather than being pieced together from simpler sensations or "atoms of experience." A musical melody, for example, is not simply a summation of the individual notes that it contains. The melody is given in experience as a whole, and the character of each individual note is determined by its place within that whole.... (Schroeder, 2007, p. 295). 
The starting point for Fuller's (1990) phenomenological account of gestalt psychology is the life world of human experience. 'Life world' (Lebenswelt) is a term coined by Husserl and Schütz to denote the original, meaningful, everyday world in which people actually live. The task of phenomenological description and interpretation is to explicate hidden structures of life world meaning that hitherto have been lived only in an implicit, unreflective way. (Schroeder, 2007, p. 299)

Seamon (1987) characterizes environmental phenomenology as "striving for a holistic view of place, in which the various parts of environmental experience are understood as reciprocally related to each other and to the larger geographical whole to which they belong" (p. 20). He describes the phenomenological essence of place as "a psycho-social environmental whole larger than the sum of its parts" (p. 20; see also Keen, 1975; McCall, 1983; Schroeder, 2007, pp. 295-296; Seamon, 1982, 1987).

\section{How Can the Quality and Influences of a Knowledge Environments be Verified?}

Research about knowledge environments uses at least two different perspectives. The first one is the life world of individual scholars: How do individuals subjectively cognize, experience, and evaluate the knowledge environment of their research group, department, or university?

According to Welskopp (2002) "All structural interrelations must . . . be tracked through the consciousness of the participants as it were, although multiple discerning rounds of translation and decoding will be necessary" (p. 76). Depending on the objectives, cognitive abilities, motivation, scientific productiveness, and social relations of an individual, that person will find his or her own widely diverse positive role models or deterrent examples, selectively follow up on various ideas, and draw different lessons from personal experience but will also be able to deal flexibly with obstacles and personal liabilities.

Most scholars have been influenced by more than one knowledge environment during their academic career. Even so, scientific careers are not a "random sequence of events" but rather a "contingent series of events" (Welskopp, 2002, p. 79) that follow a definite logic and rest on particular mechanisms. In individual cases, certain events are therefore linked with each other, and a rationale can be found for the sequence of events (e.g., the steps in a scientist's career).

The career and mobility of a scholar represents a first important hint at his or her scientific reputation (for details see Pietsch, 2017; Weick, 1995). If two or more faculties have confirmed that the scientific achievements, personal competence, and other merits of a scholar warrant that person's appointment as professor, then the uncertainty about that persons scientific potential is much lower than if the confirmation were only issued by the same faculty where the candidate had studied and graduated. From experience it can be assumed that an academic who has worked successfully at more than one university has a greater wealth of experience, more 
extensive personal networks, a broader methodological spectrum, and a better academic reputation in general than one who has worked in only one institutional setting. The analysis of a scholar's professional career is also a precondition to understand his or her networks and scientific interests. There exist many studies about the professional careers of scholars (Meusburger \& Schuch, 2010, 2012; Weick, 1995) but very few about the question of how they have personally experienced and evaluated the knowledge environments at various stages of their career (Demm, 2010; Hübner, 2010).

This approach involves the attempt to reconstruct the influences and watersheds that shaped the academic aspirations, research interests, methodological expertise, and career trajectory in various phases of the scholar's career. Most (senior) academics are able to recall with relative accuracy who decisively influenced and inspired them as students; what personal strengths and weaknesses their professors had; what intellectual standard the doctoral seminars had; the times, places, and people of the critical junctures in their professional success or failure; the time and circumstances relating to their development of a new scientific idea; the way in which their immediate social environment and their academic discipline responded to new ideas; and the reasons that particular research projects could not be pursued. The research taking this approach is based on interviews, memoires, and correspondence; the scholar's own account of his or her professional career; biographies and autobiographies; minutes of meetings; and reports by persons from the social context. This approach has a long tradition in the history of science but has rarely been used to describe knowledge environments.

The second perspective is the view from the outside. Researchers adopting it scrutinize a knowledge environment's particular elements, structures, and interrelations; analyze the long-term historical, political, and economic influences that have contributed to a department's or university's reputation and knowledge environment. They try to discern how a specific knowledge environment has come about over time and who has been and is responsible for specific positive or negative developments.

This approach can be further differentiated into two procedural methods. First, the quality of a knowledge environment of an academic institution can be studied for the scientific accomplishments, professional success, or academic reputation attained by its scholars or graduates in a given period. There are numerous questions to pursue in this regard. For instance, what pioneering publications have originated in a particular institute? What new ideas, methods, and theoretical concepts have come from a given department or faculty? How many of a department's graduates have been appointed to professorships at other universities or prominent positions outside academia? How many of a university's scholars have received outstanding scientific awards (e.g., Nobel Prize, Fields Medal, ${ }^{29}$ or honorary doctorates)? How often have its members been engaged as reviewers by major institutions of research funding or in important evaluation procedures? This first procedure allows inferences about the

\footnotetext{
${ }^{29}$ International Medal for Outstanding Discoveries in Mathematics.
} 
quality of the knowledge environment without opening the black box of causes and relations and without discussing the personal experiences of the given scholars. The method communicates the external perspective and is useful especially at the highest level of aggregation or with comparative studies that cannot delve into the biographies of numerous individual scholars. Figure 7.1 shows, for example, that former doctoral candidates and assistants of Heidelberg chemist Robert Bunsen came to occupy numerous chairs and other prominent positions in the chemistry departments throughout Europe (Eckart et al., 2012, p. 98). In addition, a number of prominent U.S. chemists had studied under Bunsen (Honeck \& Meusburger, 2012).

If so many successful scientists hail from one department, one may legitimately conclude that a very stimulating and unusually creative knowledge environment had existed there during a certain period. Such recruitment of scientists to other universities not only promotes knowledge transfer and creates important networks but generally intensifies the sway that the home institutes have over their discipline. Figure 7.1 also suggests what an international power center Heidelberg must have been in the field of chemistry during the second half of the nineteenth century. Such internationally important nodes of scientific networks often dominate the review process in appointment procedures and have a strong influence on scientific journals.

A second approach turns attention to interactions, social relations, networks of scholars, and processes of appropriation. It raises a different set of questions. For example, how do (or did) scholars interact with each other? For what reasons have some scholars been included in and other excluded from important local networks or regular jours fixes? How much are the life worlds of various disciplines at a university or in a knowledge city communicatively interlinked? Which persons or departments are the ones bridging between disciplines or serving as the key nodes in networks? How do scholars get along with the basic local conditions and power structures under which they try to reach their objectives? Processes of appropriation should not be taken for granted.

Many universities offer local resources, support networks, and opportunities that some of their academics fail to use to their own advantage. Research equipment whose potential is not fully exploited, important data bases that go unused, outstanding publications that remain unread, and potential contacts that are not activated cannot have an effect on learning and research processes. The earlier mentioned silo mentality of some academics often prevents interaction and appropriation. Therefore, the second approach focuses on personal friendships and networks of scholars (Meusburger \& Schuch, 2010), on scientific circles (Lepsius, 2012), joint publications, and various other forms of more or less regular interaction.

\section{Conclusion}

Research on knowledge environments will replace neither traditional science studies nor studies about the biographies and careers of individual scholars. However, there is a need for concepts focusing on social macrophenomena, holistic explanations, 


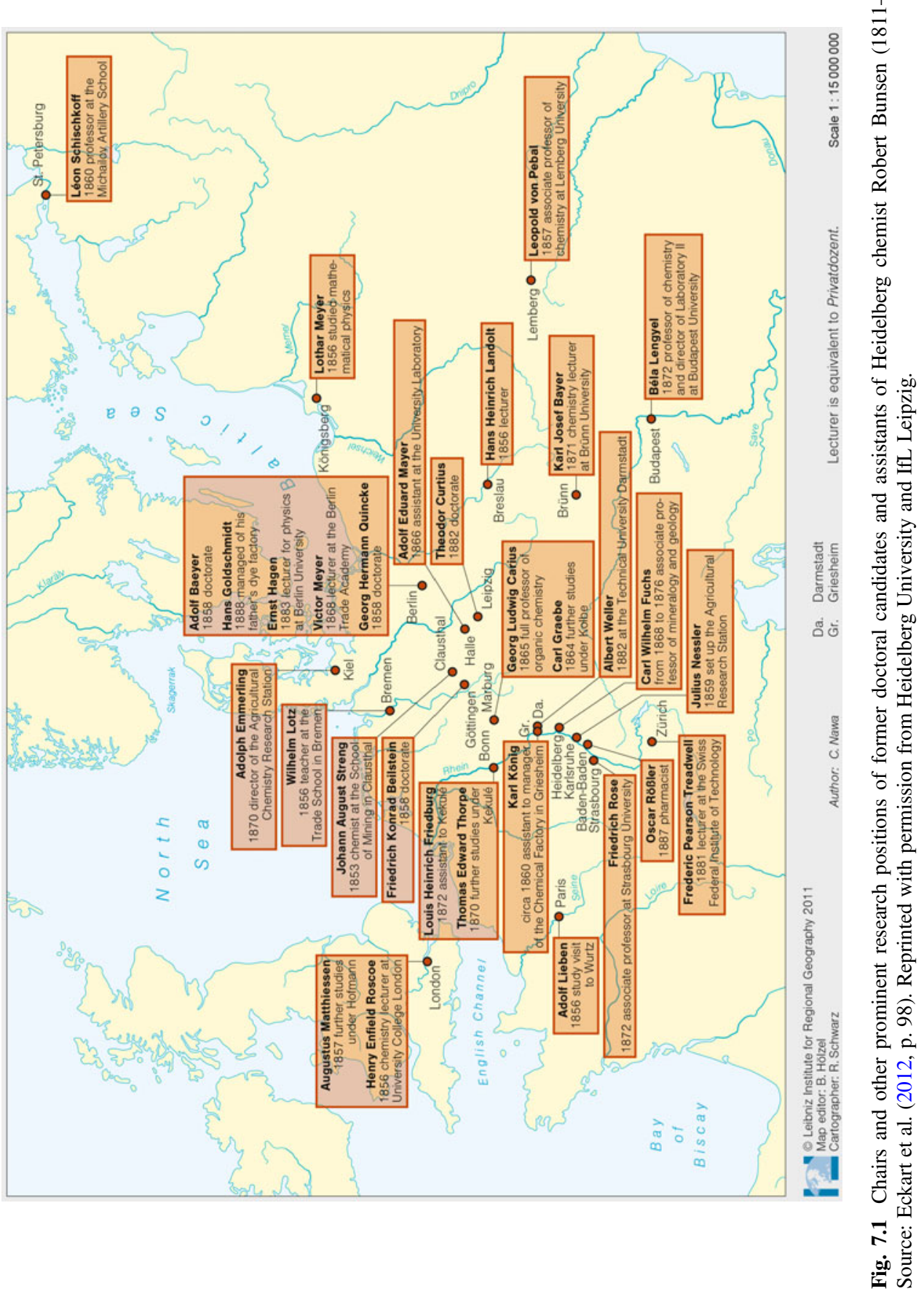


and environmental clues in the sense of Gigerenzer and his coauthors (Gigerenzer \& Gaissmaier, 2011, 2015; Gigerenzer \& Selten, 2001). Authors studying knowledge environments should be able to deal with the tension between a knowledge environment's conditionality, which is in principle historical and local, and "efforts to formulate generalizing concepts and generic explanations" (Esser, 1999, p. 128; 2002).

With the knowledge-environments approach, it is possible to analyze and reconstruct the conditions under which outstanding scientific achievements were achieved or prevented in an institute or at a university over an extended period. One begins by analyzing the recruitment of professors (Pietsch, 2017; Weick, 1995) and continues by asking what human, financial, and infrastructural resources are available and what paradigms and research cultures are dominant. It is also necessary to inquire how hostile the assessment is toward scientific project proposals and research results at certain universities (or entire states) and to what extent standardized assessment tools have curtailed the originality and creativity of academics. ${ }^{30}$

Project proposals and manuscript submissions alike have the best chances of being accepted if they conform as closely as possible to whatever the mainstream paradigm is, not contradicting it in any way and taking care not to suggest anything incommensurate with the reviewers' horizon of expectation defined by that paradigm. (Weichhart, 2012b, p. 20)

As with historical theories, knowledge environments can be credited with "a retrospective forecasting ability" (Welskopp, 2002, p. 83). In other words, it is possible to formulate a post hoc explanation of how relational networks between human and institutional agents have affected observable scientific practice (pp. 76-77). The reconstruction and description of knowledge environments after the events have taken place, however, is tied to "epistemological and discursive conditions of the present" (p. 78) and can therefore be revised the moment new information surfaces or scientific standards and criteria of judgment change.

Acknowledgments I thank my colleagues Bernhard Eitel (Heidelberg University), Joachim Funke (Heidelberg University), Peter Weichhart (University of Vienna), and Benno Werlen (University of Jena) for critical comments and valuable suggestions.

\section{References}

Amabile, T. M. (1979). Effects of external evaluation on artistic creativity. Journal of Personality and Social Psychology, 37, 221-233. doi:https://doi.org/10.1037//0022-3514.37.2.221

Amabile, T. M. (1983a). The social psychology of creativity. New York: Springer.

\footnotetext{
30" At times of the citation index, creativity, innovation, [and] genuine breakthroughs that risky hypotheses require necessarily get suppressed in favor of mainstream science" (Mocikat, 2009, p. 102; see also Liessmann, 2006, p. 131; Weichhart, 2012a, p. 21). Achieving high scores for the next assessment seems to have higher priority than the ambition to do innovative, but risky, research.
} 
Amabile, T. M. (1983b). The social psychology of creativity: A componential conceptualization. Journal of Personality and Social Psychology, 45, 357-376. doi:https://doi.org/10.1037/00223514.45.2.357

Amabile, T. M. (1996). Creativity in context. New York: Westview Press.

Amabile, T. M. Conti, R. Coon, H. Lazenby, J., \& Herron, M. (1996). Assessing the work environment for creativity. Academy of Management Journal, 39, 1154-1184. doi:https://doi. org/10.2307/256995

Amabile, T. M., Goldfarb, P., \& Brackfield, S. C. (1990). Social influences on creativity: Evaluation, co-action, and surveillance. Creativity Research Journal, 3, 6-21. doi:https://doi.org/10. 1080/10400419009534330

Amabile, T. M., \& Gryskiewicz, N. D. (1989). The creative environment scales: The work environment inventory. Creative Research Journal, 2, 231-254. doi:https://doi.org/10.1080/ 10400418909534321

Argyle, M. (1957). The scientific study of social behavior. London: Methuen.

Argyle, M. (1969). Social interaction. London: Methuen.

Argyle, M. (1991). Cooperation: The basis of sociability. London: Routledge.

Barker, R. G. (1968). Ecological psychology: Concepts and methods for studying the environment of human behavior. Stanford: Stanford University Press.

Battilana, J. (2006). Agency and institutions: The enabling role of individual's social position. Organization, 13, 653-676. doi:https://doi.org/10.1177/1350508406067008

Bechtel, R. B. (1997). Environment and behavior: An introduction. Thousand Oaks: Sage.

Beck, U. (2005). Was zur Wahl steht [What the choice is]. Frankfurt am Main: Suhrkamp.

Berger, P. L., \& Luckmann, T. (1967). The social construction of reality: A treatise in the sociology of knowledge. New York: Doubleday.

Berthoin Antal, A., Meusburger, P., \& Suarsana, L. (Eds.). (2014). Learning organizations: Extending the field. Knowledge and Space: Vol. 6. Dordrecht, The Netherlands: Springer. doi: https://doi.org/10.1007/978-94-007-7220-5

Bitektine, A., \& Miller, D. (2015). Methods, theories, data, and the social dynamics of organizational research. Journal of Management Inquiry, 24, 115-130. doi:https://doi.org/10.1177/ 1056492614546897

Boden, M. A. (1994). What is creativity? In M. A. Boden (Ed.), Dimensions of creativity (pp. 75-117). Cambridge, MA: MIT Press.

Boden, M. A. (Ed.). (2004). The creative mind: Myths and mechanisms (rev. and expanded 2nd ed.). London: Routledge.

Bundesverband Deutscher Stiftungen. (2010). Stiftungen in Zahlen: Errichtungen und Bestand rechtsfähiger Stiftungen des bürgerlichen Rechts in Deutschland im Jahr 2009 [Foundations in numbers: Creation and stock of foundations under civil law in Germany in 2009]. Berlin: Bundesverband Deutscher Stiftungen. Retrieved from https://www.stiftungen.org/uploads/tx_ leonhardtfebecm/downloads/Jahresstatistik.pdf

Canter, D. (1977). The psychology of places. London: Architectural Press.

Christmann, G. B. (2016). Das theoretische Konzept der kommunikativen Raum(re)konstruktion [The theoretical concept of the (re)construction of communicative space]. In G. B. Christmann (Ed.), Zur kommunikativen Konstruktion von Räumen: Theoretische Konzepte und empirische Analysen (pp. 89-117). Wiesbaden: Springer VS.

Clegg, S. (2010). The state, power, and agency: Missing in action in institutional theory? Journal of Management Inquiry, 19, 4-13. doi:https://doi.org/10.1177/1056492609347562

Clitheroe, H. C., Stokols, D., \& Zmuidzinas, M. (1998). Conceptualizing the context of environment and behavior. Journal of Environmental Psychology, 18, 103-112. doi:https://doi.org/10. 1006/jevp.1998.0091

Collins, H. M. (1983). The sociology of scientific knowledge: Studies of contemporary science. Annual Review of Sociology, 9, 265-285. Retrieved from https://www.jstor.org/stable/2946066

Collins, H. M. (2008). Actors' and analysts' categories in the social analysis of science. In P. Meusburger, M. Welcker, \& E. Wunder (Eds.), Clashes of knowledge: Orthodoxies and 
heterodoxies in science and religion (pp. 101-110). Knowledge and Space: Vol. 1. Dordrecht, The Netherlands: Springer. doi:https://doi.org/10.1007/978-1-4020-5555-3_4

Collins, H. M., \& Evans, R. (2002). The third wave of science studies: Studies of expertise and experience. Social Studies of Science, 32, 235-296. doi:https://doi.org/10.1177/ 0306312702032002003

Collins, H. M., \& Pinch, T. (1998). The Golem: What everyone should know about science (New ed.). Cambridge, UK: Cambridge University Press.

Cummings, L. L. (1965). Organizational climates for creativity. Academy of Management Journal, 8, 220-227. doi:https://doi.org/10.2307/254790

Dacin, M. T., Goodstein, J., \& Scott, W. R. (2002). Institutional theory and institutional change: Introduction to the special research forum. Academy of Management Journal, 45, 45-56. doi: https://doi.org/10.5465/AMJ.2002.6283388

Darwin, C. R. (1859). On the origin of species by means of natural selection, or the preservation of favoured races in the struggle for life. London: John Murray.

Demm, E. (2010). Alfred Weber (1868-1958): Machtkapital, Netzwerke und Lebensstil [Alfred Weber (1868-1958): Power capital, networks, and lifestyle]. In E. Demm \& J. Suchoples (Eds.), Akademische Lebenswelten: Habitus und Sozialprofil von Gelehrten im 19. und 20. Jahrhundert (pp. 105-135). Frankfurt am Main: Peter Lang.

Denison, D. R. (1996). What is the difference between organizational culture and organizational climate? A native's point of view on a decade of paradigm wars. Academy of Management Review, 21, 619-654. doi:https://doi.org/10.2307/258997

DeRue, D. S. (2011). Adaptive leadership theory: Leading and following as a complex adaptive process. Research in Organizational Behavior, 31, 125-150. doi:https://doi.org/10.1016/j.riob. 2011.09.007

Deutsche Forschungsgemeinschaft. (2015). Förderatlas 2015: Kennzahlen zur öffentlich finanzierten Forschung in Deutschland [Atlas of public funding, 2015: Indicators about publicly funded research in Germany]. Weinheim: Wiley-VCH Verlag.

Dörner, D. (1996). The logic of failure: Recognizing and avoiding error in complex situations. New York: Basic Books.

Dörner, D., \& Funke, J. (2017). Complex problem solving: What it is and what it is not. Frontiers in Psychology, 8(1153), 1-11. doi:https://doi.org/10.3389/fpsyg.2017.01153

Eckart, W. U., Hübner, K., \& Nawa, C. (2012). The rise of the natural sciences-Bunsen, Kirchhoff, and Helmholtz. In P. Meusburger \& T. Schuch (Eds.), Wissenschaftsatlas of Heidelberg University: Spatio-temporal relations of academic knowledge production (pp. 96-99). Knittlingen: Bibliotheca Palatina.

Ellis, H. (2017). Collaboration and knowledge exchange between scholars in Britain and the Empire, 1830-1914. In H. Jöns, P. Meusburger, \& M. Heffernan (Eds.), Mobilities of knowledge (pp. 141-155). Knowledge and Space: Vol. 10. Cham, Switzerland: Springer. doi:https://doi. org/10.1007/978-3-319-44654-7_8

Esser, H. (1999). Situationslogik und Handeln [Situational logic and action]. Soziologie: Spezielle Grundlagen: Vol. 1. Frankfurt am Main: Campus.

Esser, H. (2002). Was könnte man (heute) unter einer 'Theorie mittlerer Reichweite' verstehen? [What could one take a "middle-range theory" to mean today?]. In R. Mayntz (Ed.), AkteureMechanismen-Modelle: Zur Theoriefähigkeit makro-sozialer Analysen (pp. 128-150). Schriften des Max-Planck-Instituts für Gesellschaftsforschung Köln: Vol. 42. Frankfurt am Main \& New York: Campus.

European Foundation Centre. (2008). Foundations in the European Union: Facts and figures: Report on work by EFC Research task force. Brussels: European Foundation Centre.

Feld, S., \& Basso, K. H. (1996). Introduction. In S. Feld \& K. H. Basso (Eds.), Senses of place (pp. 3-11). Santa Fe: School of American Research Press.

Fiedler, K. (2004). Tools, toys, truisms, and theories: Some thoughts on the creative cycle of theory formation. Personality and Social Psychology Review, 8, 123-131. doi:https://doi.org/10.1207/ s15327957pspr0802_5 
Fleck, L. (1979). Genesis and development of a scientific fact (F. Bradley \& T. J. Trenn, Trans.; T. J. Trenn \& R. K. Merton, Eds.; with a Foreword by T. S. Kuhn). Chicago: University of Chicago Press. (Original work published 1935)

Fligstein, N. (2013). Understanding stability and change in fields. Research in Organizational Behavior, 33, 39-51. doi:https://doi.org/10.1016/j.riob.2013.10.005

Florida, R. (2002). The rise of the creative class: And how it's transforming work, leisure, community and everyday life. New York: Basic Books.

Florida, R. L. (2005). Cities and the creative class. New York: Routledge.

Franzen, M. (2011). Breaking News: Wissenschaftliche Zeitschriften im Kampf um Aufmerksamkeit [Breaking news: Scientific journals in the battle for attention]. Wissenschafts- und Technikforschung: Vol. 5. Baden-Baden: Nomos.

Franzen, M. (2015). Der Impact Faktor war gestern: Altmetrics und die Zukunft der Wissenschaft [The impact factor was yesterday: Altmetrics and the future of science]. Soziale Welt, 66, 225-242. doi:https://doi.org/10.5771/0038-6073-2015-2-225

Franzen, M. (2017). Digitale Resonanz: Neue Bewertungskulturen fordern die Wissenschaft heraus [Digital resonance: New evaluation cultures challenge science]. WZB Mitteilungen, 155, 30-33. Retrieved from https://www.wzb.eu/sites/default/files/publikationen/wzb_mitteilungen/3033 franzenwm155web.pdf

Frey, B., \& Iselin, D. (Eds.). (2017). Economic ideas you should forget. Cham, Switzerland: Springer.

Fuller, A. R. (1990) Insight into value: An exploration of the premises of a phenomenological psychology. Albany: State University of New York Press.

Funke, J. (2012). Complex problem solving. In N. M. Seel (Ed.), Encyclopedia of the sciences of learning: Vol. 2 (pp. 682-685). Heidelberg: Springer.

Furnham, A. (Ed.). (1985). Social behavior in context. London: Allyn and Bacon.

Giddens, A. (1979). Central problems in social theory: Action, structure and contradiction in social analysis. London: MacMillan.

Giddens, A. (1984). The constitution of society: Outline of the theory of structuration. Cambridge, UK: Polity Press.

Gieryn, T. F. (1983). Boundary-work and the demarcation of science from non-science: Strains and interests in professional ideologies of scientists. American Sociological Review, 48, 781-795. doi:https://doi.org/10.2307/2095325

Gieryn, T. F. (2000). A space for place in sociology. Annual Review of Sociology, 26, 463-496. doi:https://doi.org/10.1146/annurev.soc.26.1.463

Gieryn, T. F. (2002). Give place a chance: Reply to Gans. City \& Community, 1, 341-343. doi: https://doi.org/10.1111/1535-6841.00034

Gigerenzer, G., \& Gaissmaier, W. (2011). Heuristic decision making. Annual Review of Psychology, 62, 451-482. doi:https://doi.org/10.1146/annurev-psych-120709-145346

Gigerenzer, G., \& Gaissmaier, W. (2015). Decision making: Nonrational theories. In J. D. Wright (Ed.), International encyclopedia of the social \& behavioral sciences: Vol. 5 (2nd ed., pp. 911-916). Amsterdam: Elsevier. doi:https://doi.org/10.1016/B978-0-08-097086-8.26017-0W

Gigerenzer, G., \& Selten, R. (Eds.). (2001). Bounded rationality: The adaptive toolbox. Cambridge, MA: MIT Press.

Glückler, J., Lazega, E., \& Hammer, I. (Eds.). (2017). Knowledge and networks. Knowledge and Space: Vol. 11. Cham, Switzerland: Springer. doi:https://doi.org/10.1007/978-3-319-45023-0

Glückler, J., \& Ries, M (2012). Why being there is not enough: Organized proximity in place-based philanthropy. Service Industries Journal, 32, 515-529. doi:https://doi.org/10.1080/02642069. 2011.596534

Graumann, C. F.(Ed.). (1978). Ökologische Perspektiven in der Psychologie [Ecological perspectives in psychology]. Bern: Huber.

Graumann, C. F. (1983). On multiple realities. International Social Science Journal, 35, 309-321. 
Graumann, C. F. (1996). Aneignung [Appropriation]. In L. Kruse, C.-F. Graumann, \& E.-D. Lantermann (Eds.), Ökologische Psychologie: Ein Handbuch in Schlüsselbegriffen (pp. 124-130). Weinheim: Psychologie Verlags Union.

Graumann, C. F. (2002a). Auf dem Wege zu einer humanökologischen Psychologie: Zu Florian Kaisers Replik [On the way to human-ecological psychology: An answer to Florian Kaiser's reply]. Umweltpsychologie, 6, 82-83.

Graumann, C. F. (2002b). The phenomenological approach to people-environment studies. In R. B. Bechtel \& A. Churchman (Eds.), Handbook of environmental psychology (pp. 95-113). New York: John Wiley \& Sons.

Graumann, C. F. (2002c). Zwischen den Disziplinen: Dilemma und Chancen der Umweltpsychologie [Between the disciplines: Dilemma and opportunities of environmental geography]. Umweltpsychologie, 6, 154-161. Retrieved from http://www.umps.de/php/suche. php?heftid=11

Graumann, C. F., \& Kruse, L. (1990). The environment: Societal construction and psychological problems. In H. T. Himmelweit \& G. Gaskell (Eds.), Societal psychology (pp. 221-229). Newbury Park: Sage.

Graumann, C. F., \& Kruse, L. (2003). Räumliche Umwelt: Die Perspektive der humanökologisch orientierten Umweltpsychologie [Spatial environment: The perspective of an environmental psychology oriented to human ecology]. In P. Meusburger \& T. Schwan (Eds.), Humanökologie: Ansätze zur Überwindung der Natur-Kultur-Dichotomie (pp. 239-256). Erdkundliches Wissen: Vol. 135. Stuttgart: Steiner.

Haeckel, E. (1866). Generelle Morphologie der Organismen [General morphology of organisms]. 2 Vols. Berlin: Reimer.

Haeckel, E. (1868). Natürliche Schöpfungsgeschichte: Gemeinverständliche wissenschaftliche Vorträge über die Entwickelungslehre im Allgemeinen und diejenige von Darwin, Goethe und Lamarck im Besonderen [Natural history of creation in general and that of Darwin, Goethe, and Lamarck in particular]. Berlin: Reimer.

Harvey, D. (1969). Explanations in geography. London: Arnold.

Harvey, D. (2005). Space as a key word. In D. Harvey (Ed.), Spaces of neoliberalization: Towards a theory of uneven geographical development (pp. 93-115). Hettner-Lecture: Vol. 8. Stuttgart: Steiner.

Heffernan, M. (1994). A state scholarship: The political geography of French international science during the nineteenth century. Transactions of the Institute of British Geographers, New Series, 19, 21-45. Retrieved from https://www.jstor.org/stable/622444

Heffernan, M., \& Jöns, H. (2013). Research travel and disciplinary identities in the University of Cambridge, 1885-1955. The British Journal for the History of Science, 46, 255-286. doi: https://doi.org/10.1017/S000708741200074X

Hennessey, B. A., \& Amabile, T. M. (1988). The conditions of creativity. In R. J. Sternberg (Ed.), The nature of creativity: Contemporary psychological perspectives (pp. 11-38). Cambridge, UK: Cambridge University Press.

Honeck, M., \& Meusburger, P. (2012). American students up to 1914. In P. Meusburger \& T. Schuch (Eds.), Wissenschaftsatlas of Heidelberg University: Spatio-temporal relations of academic knowledge production (pp. 296-299). Knittlingen: Bibliotheca Palatina.

Hübner, K. (2010). Gustav Robert Kirchhoff: Das gewöhnliche Leben eines außergewöhnlichen Mannes [Gustav Robert Kirchhoff: The ordinary life of an extraordinary man]. Schriften/Archiv und Museum der Universität Heidelberg: Vol. 16. Heidelberg: Verlag Regionalkultur.

Hudson, B. A., Okhuysen, G. A., \& Creed, W. E. D. (2015). Power and institutions: Stones in the road and some yellow bricks. Journal of Management Inquiry, 24, 233-238. doi:https://doi.org/ $10.1177 / 1056492614565240$

Jöns, H. (2003). Grenzüberschreitende Mobilität und Kooperation in den Wissenschaften Deutschlandaufenthalte US-amerikanischer Humboldt-Forschungspreisträger aus einer erweiterten Akteursnetzwerkperspektive [Transnational mobility and cooperation in the sciences: U.S. Humboldt Research Award winners in Germany from an expanded actor-network 
perspective]. Heidelberger Geographische Arbeiten: Vol. 116. Heidelberg: Selbstverlag des Geographischen Instituts.

Jöns, H. (2007). Transnational mobility and the spaces of knowledge production: A comparison of global patterns, motivations and collaborations in different academic fields. Social Geography, 2, 97-114. doi:https://doi.org/10.5194/sg-2-97-2007

Jöns, H. (2008). Academic travel from Cambridge University and the formation of centres of knowledge, 1885-1954. Journal of Historical Geography, 34, 338-362. doi:https://doi.org/ 10.1016/j.jhg.2007.11.006

Jöns, H. (2009). 'Brain circulation' and transnational knowledge networks: Studying long-term effects of academic mobility to Germany, 1954-2000. Global Networks, 9, 315-338. doi: https://doi.org/10.1111/j.1471-0374.2009.00256.x

Jöns, H. (2017). The University of Cambridge, academic expertise, and the British Empire, 1885-1962. In H. Jöns, P. Meusburger, \& M. Heffernan (Eds.), Mobilities of knowledge (pp. 185-210). Knowledge and Space: Vol. 10. Cham, Switzerland: Springer. doi:https://doi.org/10. 1007/978-3-319-44654-7_10

Keen, E. (1975). A primer in phenomenological psychology. New York: Holt, Rinehart \& Winston.

Keller, R., Knoblauch, H., \& Reichertz, J. (2013). Der Kommunikative Konstruktivismus als Weiterführung des Sozialkonstruktivismus: Eine Einführung in den Band [Communicative constructivism as a continuation of social constructionism: An introduction to the volume]. In R. Keller, H. Knoblauch, \& J. Reichertz (Eds.), Kommunikativer Konstruktivismus: Theoretische und empirische Arbeiten zu einem neuen wissenssoziologischen Ansatz (pp. 9-21). Wiesbaden: Springer VS.

Kelly, G. A. (1991). The psychology of personal constructs. London: Routledge. (Original work published 1955)

Klüter, H. (1986). Raum als Element sozialer Kommunikation [Space as an element of social communication]. Gießener Geographische Schriften: Vol. 60. Gießen: Selbstverlag des Geographischen Instituts.

Klüter, H. (1999). Raum und Organisation [Space and organization]. In P. Meusburger (Ed.), Handlungszentrierte Sozialgeographie: Benno Werlens Entwurf in kritischer Diskussion (pp. 187-212). Erdkundliches Wissen: Vol. 130. Stuttgart: Steiner.

Klüter, H. (2003). Raum als Umgebung [Space as environment]. In P. Meusburger \& T. Schwan (Eds.), Humanökologie: Ansätze zur Überwindung der Natur-Kultur-Dichotomie (pp. 217 238). Erdkundliches Wissen: Vol. 135. Stuttgart: Steiner.

Knoblauch, H. (1995). Kommunikationskultur: Die kommunikative Konstruktion kultureller Kontexte [Communication culture: The communicational construction of cultural contexts]. New York: de Gruyter.

Knoblauch, H. (2016). Über die kommunikative Konstruktion der Wirklichkeit [On the communicative construction of reality]. In G. B. Christmann (Ed.), Zur kommunikativen Konstruktion von Räumen: Theoretische Konzepte und empirische Analysen (pp. 29-53). Wiesbaden: Springer VS.

Knorr-Cetina, K. (1999). Epistemic cultures: How the sciences make knowledge. Cambridge, MA: Harvard University Press.

Kruse, L. (1986). Drehbücher für Verhaltensschauplätze-oder Scripts für Settings [Scripts for behavioral scenes—or scripts for settings]. In G. Kaminski (Ed.), Ordnung und Variabilität im Alltagsgeschehen (pp. 135-153). Göttingen: Hogrefe.

Kruse, L., Graumann, C. F., \& Lantermann, E-D. (Eds.). (1990). Ökologische Psychologie: Ein Handbuch in Schlüsselbegriffen [Ecological psychology: A handbook in key words]. Munich: Psychologie Verlags-Union.

Kuhn, T. S. (1962). The structure of scientific revolutions. Chicago: University of Chicago Press.

Latour, B. (1987). Science in action: How to follow scientists and engineers through society. Cambridge, MA: Harvard University Press.

Latour, B. (1999). Pandora's hope: Essays on the reality of science studies. Cambridge, MA: Harvard University Press. 
Lawrence, T. B., Suddaby, R., \& Leca B. (2011). Institutional work: Refocusing institutional studies of organization. Journal of Management Inquiry, 20, 52-58. doi:https://doi.org/10. $1177 / 1056492610387222$

Lefebvre, H. (1991). The production of space (D. Nicholson-Smith, Trans.). Oxford, UK: Basil Blackwell. (Original work published 1974)

Lepsius, R. M. (2012). Intellectual circles at the beginning of the 20th century. In P. Meusburger \& T. Schuch (Eds.), Wissenschaftsatlas of Heidelberg University: Spatio-temporal relations of academic knowledge production (pp. 112-113). Knittlingen: Bibliotheca Palatina.

Lind, E. A., \& van den Bos, K. (2013). Freeing organizational behavior from inhibitory constraints. Research in Organizational Behavior, 33, 79-95. doi:https://doi.org/10.1016/j.riob.2013.10. 001

Liessmann, K. P. (2006). Theorie der Unbildung: Die Irrtümer der Wissensgesellschaft [Theory on the lack of education: The errors of the knowledge society]. Vienna: Zsolnay.

Lippuner, R. (2005). Raum-Systeme-Praktiken: Zum Verhältnis von Alltag, Wissenschaft und Geographie [Space, systems, practices: On the relation between everyday life, science, and geography]. Sozialgeographische Bibliothek: Vol. 2. Stuttgart: Steiner.

Lippuner, R., \& Lossau, J. (2004). In der Raumfalle: Eine Kritik des spatial turn in den Sozialwissenschaften [Caught in the space trap: A critique of the spatial turn in the social sciences]. In G. Mein \& M. Riegler-Ladich (Eds.), Soziale Räume und kulturelle Praktiken: Über den strategischen Gebrauch von Medien (pp. 47-64). Bielefeld: transcript.

Livingstone, D. N. (1995). The spaces of knowledge: Contributions towards a historical geography of science. Environment and Planning D: Society and Space, 13, 5-34. doi:https://doi.org/10. 1068/d130005

Livingstone, D. N. (2000). Making space for science. Erdkunde, 54, 285-296. doi:https://doi.org/ 10.3112/erdkunde.2000.04.01

Livingstone, D. N. (2002). Knowledge, space and the geographies of science. In D. N. Livingston (Ed.), Science, space and hermeneutics (pp. 7-40). Hettner-Lecture: Vol. 5. Heidelberg: Department of Geography, Heidelberg University.

Livingstone, D. N. (2003). Putting science in its place: Geographies of scientific knowledge. Chicago: University of Chicago Press.

Livingstone, D. N. (2005). Text, talk and testimony: Geographical reflections on scientific habitsAn afterword. British Journal for the History of Science, 38, 93-100. doi:https://doi.org/10. 1017/S000708740400648X

Livingstone, D. N. (2010). Landscapes of knowledge. In P. Meusburger, D. Livingstone, \& H. Jöns (Eds.), Geographies of science (pp. 3-22). Knowledge and Space: Vol. 3. Dordrecht, The Netherlands: Springer. doi:https://doi.org/10.1007/978-90-481-8611-2_1

Mager, C. (2012). Heidelberg Nobel Prize winners. In P. Meusburger \& T. Schuch (Eds.), Wissenschaftsatlas of Heidelberg University: Spatio-temporal relations of academic knowledge production (pp. 250-253). Knittlingen: Bibliotheca Palatina.

Manzo, L. C. (2005). For better or worse: Exploring multiple dimensions of place meaning. Journal of Environmental Psychology, 25, 67-86. doi:https://doi.org/10.1016/j.jenvp.2005.01.002

Marquis, C., \& Battilana, J. (2009). Acting globally but thinking locally? The enduring influence of local communities on organizations. Research in Organizational Behavior, 29, 283-302. doi: https://doi.org/10.1016/j.riob.2009.06.001

Massey, D. B. (1985). New directions in space. In D. Gregory \& J. Urry (Eds.), Social relations and spatial structures (pp. 9-19). New York: St. Martin's Press.

Massey, D. B. (1999a). Imagining globalisation: Power-geometries of time-space. In D. B. Massey (Ed.), Power-geometries and the politics of space-time (pp. 9-23). Hettner-Lecture: Vol. 2. Heidelberg: Department of Geography, Heidelberg University.

Massey, D. B. (1999b). Philosophy and politics of spatiality: Some considerations. In D. B. Massey, Power-geometries and the politics of space-time (pp. 27-42). Hettner-Lecture: Vol. 2. Heidelberg: Department of Geography, Heidelberg University.

Massey, D. B. (2005). For space. London: Sage. 
Matthiesen, U. (2006). Raum und Wissen: Wissensmilieus und Knowledge Scapes als Inkubatoren für zukunftsfähige stadtregionale Entwicklungsdynamiken? [Space and Knowledge: Knowledge milieus and knowledge scapes as incubators for sustainable urban development dynamics]. In D. Tänzler, H. Knoblauch, \& H.-G. Soeffner (Eds.), Zur Kritik der Wissensgesellschaft (pp. 155-188). Erfahrung-Wissen-Imagination: Vol. 12. Constance: UVK.

Matthiesen, U. (2007). Wissensmilieus und KnowledgeScapes [Knowledge milieus and knowledgescapes]. In R. Schützeichel (Ed.), Handbuch Wissenssoziologie und Wissensforschung (pp. 679-693). Erfahrung-Wissen-Imagination: Vol. 15. Constance: UVK.

Mayntz, R. (2002). Zur Theoriefähigkeit makro-sozialer Analysen [The theory-generating ability of macrosocial analyses]. In R. Mayntz (Ed.), Akteure-Mechanismen-Modelle: Zur Theoriefähigkeit makro-sozialer Analysen (pp. 7-43). Schriften des Max-Planck-Instituts für Gesellschaftsforschung Köln: Vol. 42. Frankfurt am Main \& New York: Campus.

McCall, R. J. (1983). Phenomenological psychology: An introduction. Madison: The University of Wisconsin Press.

Meusburger, P. (2008). The nexus of knowledge and space. In P. Meusburger, M. Welker, \& E. Wunder (Eds.), Clashes of knowledge: Orthodoxies and heterodoxies in science and religion (pp. 35-90). Knowledge and Space: Vol. 1. Dordrecht, The Netherlands: Springer. doi:https:// doi.org/10.1007/978-1-4020-5555-3_2

Meusburger, P. (2009). Milieus of creativity: The role of places, environments, and spatial contexts. In P. Meusburger, J. Funke, \& E. Wunder (Eds.), Milieus of creativity: An interdisciplinary approach to spatiality of creativity (pp. 97-153). Knowledge and Space: Vol. 2. Dordrecht: Springer. doi:https://doi.org/10.1007/978-1-4020-9877-2_7

Meusburger, P. (2012a). Heidelberg: Relations between a town and its university. In P. Meusburger \& T. Schuch (Eds.), Wissenschaftsatlas of Heidelberg University: Spatio-temporal relations of academic knowledge production (pp. 18-35). Knittlingen: Bibliotheca Palatina.

Meusburger, P. (2012b). Wissenschaftsatlas of Heidelberg University-An introduction. In P. Meusburger \& T. Schuch (Eds.), Wissenschaftsatlas of Heidelberg University: Spatiotemporal relations of academic knowledge production (pp. 12-17). Knittlingen: Bibliotheca Palatina.

Meusburger, P. (2015). Knowledge environments in universities. Hungarian Geographical Bulletin, 64, 265-279. doi:https://doi.org/10.15201/hungeobull.64.4.1

Meusburger, P. (2016). Zur Bedeutung und Wirkung von Wissensmilieus [The importance and effectiveness of knowledge milieus]. In A. Froese, D. Simon, \& J. Böttcher (Eds.), Sozialwissenschaften und Gesellschaft: Neue Verortungen von Wissenstransfer (pp. 263-306). Bielefeld: transcript.

Meusburger, P. (2017). Spatial mobility of knowledge: Communicating different categories of knowledge. In H. Jöns, P. Meusburger, \& M. Heffernan (Eds.), Mobilities of knowledge (pp. 23-50). Knowledge and Space: Vol. 10. Cham, Switzerland: Springer. doi:https://doi.org/10. 1007/978-3-319-44654-7_2

Meusburger, P., \& Schuch, T. (2010). Karrieren, soziale Herkunft und räumliche Mobilität der Heidelberger Professoren 1803-1932 [Careers, social origin, and spatial mobility of Heidelberg University's professors, 1803-1932]. In E. Demm \& J. Suchoples (Eds.), Akademische Lebenswelten. Habitus und Sozialprofil von Gelehrten im 19. und 20. Jahrhundert (pp. 217-249). Frankfurt am Main: Peter Lang.

Meusburger, P., \& Schuch, T. (Eds.). (2012). Wissenschaftsatlas of Heidelberg University: Spatiotemporal relations of academic knowledge production. Knittlingen: Bibliotheca Palatina.

Meusburger, P., \& Werlen, B. (2017). Knowledge, action, and space: An introduction. In P. Meusburger, B. Werlen, \& L. Suarsana (Eds.), Knowledge and action (pp. 1-30). Knowledge and Space: Vol. 9. Cham, Switzerland Springer. doi:https://doi.org/10.1007/978-3-319-445885_1

Meyer, M. W., \& Gupta, V. (1994). The performance paradox. Research in Organizational Behavior, 16, 309-369. 
Mintzberg, H. (1979). The structuring of organizations: A synthesis of the research. Englewood Cliffs: Prentice Hall.

Mocikat, R. (2009). Die Diktatur der Zitatenindizes: Folgen für die Wissenskultur. Reaktion auf V. Winiwarter und H.-J. Luhmann. 2009. Die Vermessung der Wissenschaft. GAIA 18/1:1 [The tyranny of citation indices: Implications for the culture of knowledge. Reaction to $\mathrm{V}$. Winiwarter and H.-J. Luhmann. 2009. The survey of science. GAIA, 18/1:1]. GAIA, 18, 100-103. Retrieved from http://www.adawis.de/admin/upload/navigation/data/GAIA.pdf

Mußgnug, D. (2012). Dismissal and persecution of lecturers under National Socialism. In P. Meusburger \& T. Schuch (Eds.), Wissenschaftsatlas of Heidelberg University: Spatiotemporal relations of academic knowledge production (pp. 136-137). Knittlingen: Bibliotheca Palatina.

Neumaier, M. (2012). Destruction and rebuilding: The university between 1689 and 1803. In P. Meusburger \& T. Schuch (Eds.), Wissenschaftsatlas of Heidelberg University: Spatiotemporal relations of academic knowledge production (pp. 72-75). Knittlingen: Bibliotheca Palatina.

Pfetsch, F. R. (1974). Zur Entwicklung der Wissenschaftspolitik in Deutschland 1750-1914 [On the development of science policies in Germany, 1750-1914]. Berlin: Duncker \& Humblot.

Pietsch, T. (2017). Geographies of selection: Academic appointments in the British academic world, 1850-1939. In H. Jöns, P. Meusburger, \& M. Heffernan (Eds.), Mobilities of knowledge (pp. 157-183). Knowledge and Space: Vol. 10. Cham, Switzerland: Springer. doi:https://doi. org/10.1007/978-3-319-44654-7_9

Raffestin, C. (1989). Théories du reél et de geographicité [Theories of the real and of geographicity]. Espaces Temps, 40, 26-31. Retrieved from http://www.persee.fr/doc/espat_ 0339-3267_1989_num_40_1_3454

Rotzoll, M. (2012). Plagues and wars in the early history of Heidelberg University. In P. Meusburger \& T. Schuch (Eds.), Wissenschaftsatlas of Heidelberg University: Spatiotemporal relations of academic knowledge production (pp. 52-53). Knittlingen: Bibliotheca Palatina.

Rowles, G. D. (2008a). The meaning of place. In E. B. Crepeau, E. S. Cohn, \& B. A. Boyt Schell (Eds.), Willard and Spackman's occupational therapy (11th ed., pp. 80-89). Philadelphia: Wolters Kluwer/Lippincott Williams \& Wilkins.

Rowles, G. D. (2008b). Place in occupational science: A life course perspective on the role of environmental context in the quest for meaning. Journal of Occupational Science, 15, 127-135. doi:https://doi.org/10.1080/14427591.2008.9686622

Runco, M. A. (Ed.). (1994). Problem finding, problem solving, and creativity. Norwood: Ablex.

Runco, M. A., \& Okuda, S. M. (1988). Problem discovery, divergent thinking, and the creative process. Journal of Youth and Adolescence, 17, 211-220. doi:https://doi.org/10.1007/ BF01538162

Scannel, L., \& Gifford, R. (2010). Defining place attachment: A tripartite organizing framework. Journal of Environmental Psychology, 30, 1-10. doi:https://doi.org/10.1016/j.jenvp.2009.09. 006

Scharpf, F. W. (2002). Kontingente Generalisierung in der Politikforschung [Contingent generalization in political science]. In R. Mayntz (Ed.), Akteure-Mechanismen-Modelle: Zur Theoriefähigkeit makro-sozialer Analysen (pp. 213-235). Schriften des Max-Planck-Instituts für Gesellschaftsforschung Köln: Vol. 42. Frankfurt am Main \& New York: Campus.

Schmid, C. (2005). Stadt, Raum und Gesellschaft: Henri Lefebvre und die Theorie der Produktion des Raumes [City, space, and society: Henri Lefebvre and the theory of the production of space]. Sozialgeographische Bibliothek: Vol. 1. Stuttgart: Steiner.

Schroeder, H. W. (2007). Place experience, gestalt, and the human-nature relationship. Journal of Environmental Psychology, 27, 293-309. doi:https://doi.org/10.1016/j.jenvp.2007.07.001

Schurz, G. (1998). Koexistenzweisen rivalisierender Paradigmen: Eine begriffsklärende und problemtypologisierende Studie [Coexistence of rival paradigms: A study on terms and types 
of problems]. In G. Schurz \& P. Weingartner (Eds.), Koexistenz rivalisierender Paradigmen: Eine post-kuhnsche Bestandsaufnahme zur Struktur gegenwärtiger Wissenschaft (pp. 1-51). Opladen: Westdeutscher Verlag.

Scott, J. C. (1985). Weapons of the weak: Everyday forms of peasant resistance. New Haven: Yale University Press.

Seamon, D. (1982). The phenomenological contribution to environmental psychology. Journal of Environmental Psychology, 2, 119-140. doi:https://doi.org/10.1016/S0272-4944(82)80044-3

Seamon, D. (1987). Phenomenology and environment-behavior research. In E. H. Zube \& G. T. Moore (Eds.), Advances in environment, behavior, and design: Vol. 1 (pp. 3-27). New York: Plenum Press.

Soja, E. W. (1980). The socio-spatial dialectic. Annals of the Association of American Geographers, 70, 207-225. doi:https://doi.org/10.1111/j.1467-8306.1980.tb01308.x

Soja, E. W. (1985). The spatiality of social life: Towards a transformative retheorisation. In D. Gregory \& J. Urry (Eds.), Social relations and spatial structures (pp. 90-127). London: Macmillan.

Sternberg, R. J., \& Lubart, T. I. (1991). An investment theory of creativity and its development. Human Development, 34, 1-31. doi:https://doi.org/10.1159/000277029

Sternberg, R. J., \& Lubart T. I. (1999). The concept of creativity: Prospects and paradigms. In R. J. Sternberg (Ed.), Handbook of creativity (pp. 3-15). Cambridge, UK: Cambridge University Press.

Suddaby, R. (2010). Challenges for institutional theory. Journal of Management Inquiry, 19, 14 20. doi:https://doi.org/10.1177/1056492609347564

Suddaby, R., Elsbach, K. D., Greenwood, R., Meyer, J. W., \& Zilber T. B. (2010). Organizations and their institutional environments: Bringing meaning, values, and culture back in: Introduction to the special research forum. Academy of Management Journal, 53, 1234-1240. doi: https://doi.org/10.5465/AMJ.2010.57317486

Suddaby, R., \& Greenwood, R. (2005). Rhetorical strategies of legitimacy. Administrative Science Quarterly, 50, 35-67. doi:https://doi.org/10.2189/asqu.2005.50.1.35

Trenn, T. J., \& Merton, R. K. (1979). Commentary and annotation. In L. Fleck, Genesis and development of a scientific fact (pp. 149-165). Chicago: University of Chicago Press. (Original work published 1935)

Weichhart, P. (1996). Die Region: Chimäre, Artefakt oder Strukturprinzip sozialer Systeme? [The region: Chimera, artifact, or structural principle of social systems]. In G. Brunn (Ed.), Region und Regionsbildung in Europa: Konzeptionen der Forschung und empirische Befunde (pp. 25-43). Schriftenreihe des Instituts für Europäische Regionalforschung: Vol. 1. BadenBaden: Nomos.

Weichhart, P. (1999). Die Räume zwischen den Welten und die Welt der Räume: Zur Konzeption eines Schlüsselbegriffs der Geographie [The spaces between the worlds and the world of spaces: On the inception of a key concept of geography]. In P. Meusburger (Ed.), Handlungszentrierte Sozialgeographie: Benno Werlens Entwurf in kritischer Diskussion (pp. 67-94). Erdkundliches Wissen: Vol. 130. Stuttgart: Steiner.

Weichhart, P. (2003). Gesellschaftlicher Metabolismus und Action Settings: Die Verknüpfung von Sach- und Sozialstrukturen im alltagsweltlichen Handeln [Social metabolism and action settings: The link between technical and social structures in everyday action]. In P. Meusburger \& T. Schwan (Eds.), Humanökologie: Ansätze zur Überwindung der Natur-Kultur-Dichotomie (pp. 15-44). Erdkundliches Wissen: Vol. 135. Stuttgart: Steiner.

Weichhart, P. (2012a). "Slow Science" versus Exzellenzstalinismus: Vom Nutzen wissenschaftlicher Reflexion abseits der Evaluierungsbuchhaltung ["Slow science" versus excellence Stalinism: About the usefulness of scientific reflections beyond evaluation bookkeeping]. In M. M. Seebacher (Ed.), Raumkonstruktionen in der Geographie: Eine paradigmenspezifische Darstellung gesellschaftlicher und fachspezifischer Konstruktions-, Rekonstruktions- und Dekonstruktionsprozesse von „Räumlichkeit“ (pp. 7-38). Abhandlungen zur Geographie und 
Regionalforschung: Vol. 14. Vienna: Department of Geography and Regional Research, University of Vienna.

Weichhart, P. (2012b). Wie „funktioniert“ ein Paradigma? [How does a paradigm "function”?]. In H. Fassmann \& T. Glade (Eds.), Geographie für eine Welt im Wandel (pp. 53-64). Göttingen: Vienna University Press.

Weick, C. M. (1995). Räumliche Mobilität und Karriere: Eine individualstatistische Analyse der baden-württembergischen Universitätsprofessoren unter besonderer Berücksichtigung demographischer Strukturen [Spatial mobility and career: A statistical analysis of university professors in Baden-Württemberg with special focus on demographic structures]. Heidelberger Geographische Arbeiten: Vol. 101. Heidelberg: Department of Geography, Heidelberg University.

Welskopp, T. (2002). Die Theoriefähigkeit der Geschichtswissenschaft [The theory-generating ability of historical science]. In R. Mayntz (Ed.), Akteure-Mechanismen-Modelle: Zur Theoriefähigkeit makro-sozialer Analysen (pp. 61-90). Schriften des Max-Planck-Instituts für Gesellschaftsforschung Köln: Vol. 42. Frankfurt am Main: Campus.

Werlen, B. (1983). Zur empirischen Forschung in der Sozialgeographie [Empirical research in social geography]. Veröffentlichungen der Schweizerischen Geographischen Kommission, 7, 11-22.

Werlen, B. (1987). Gesellschaft, Handlung und Raum: Grundlagen handlungstheoretischer Sozialgeographie [Society, action, and space: Principles of social geography based on action theory] (3rd ed.). Erdkundliches Wissen: Vol. 89. Stuttgart: Steiner.

Werlen, B. (1993). Society, action and space: An alternative human geography (G. Walls, Trans., with a preface by A. Giddens). London: Routledge.

Werlen, B. (1995). Sozialgeographie alltäglicher Regionalisierungen: Bd. 1. Zur Ontologie von Gesellschaft und Raum [Social geography of everyday regionalizations: Vol. 1. On the ontology of society and space]. Erdkundliches Wissen: Vol. 116. Stuttgart: Steiner.

Werlen, B. (1996). Die Geographie globalisierter Lebenswelten [The geography of globalized life worlds]. Österreichische Zeitschrift für Soziologie, 21(2), 97-128.

Werlen, B. (1997a). Social geography. In L. Embree, J. Kokelmans, \& R. Zaner (Eds.), The encyclopedia of phenomenology (pp. 645-650). Contributions to Phenomenology: Vol. 18. Dordrecht: Kluwer.

Werlen, B. (1997b). Sozialgeographie alltäglicher Regionalisierungen: Bd. 2. Globalisierung, Region und Regionalisierung [Social geography of everyday regionalizations: Vol. 2. Globalization, region, and regionalization]. Erdkundliches Wissen: Vol. 119. Stuttgart: Steiner.

Werlen, B. (2010a). Gesellschaftliche Räumlichkeit: Bd. 1. Orte der Geographie [Societal spatiality: Vol. 1. Places of geography]. Stuttgart: Steiner.

Werlen, B. (2010b). Gesellschaftliche Räumlichkeit: Bd. 2. Konstruktion geographischer Wirklichkeiten [Societal spatiality: Vol. 2. Construction of geographical realities]. Stuttgart: Steiner.

Werlen, B. (2017). Action, knowledge, and social relations of space. In P. Meusburger, B. Werlen, \& L. Suarsana (Eds.), Knowledge and action (pp. 1-30). Knowledge and Space: Vol. 9. Cham, Switzerland: Springer. doi:https://doi.org/10.1007/978-3-319-44588-5_2

Willmott, H. (2015). Why institutional theory cannot be critical. Journal of Management Inquiry, 24, 105-111. doi:10.1177/1056492614545306

Withers, C. W. J. (2001). Geography, science and national identity: Scotland since 1520. Cambridge, UK: Cambridge University Press.

Withers, C. W. J. (2002). The geography of scientific knowledge. In N. A. Rupke (Ed.), Göttingen and the development of the natural sciences (pp. 9-18). Göttingen: Wallstein.

Withers, C. W. J. (2010). Geographies of science and public understanding? Exploring the reception of the British Association for the Advancement of Science in Britain and in Ireland, c.1845-1939. In P. Meusburger, D. Livingstone, \& H. Jöns (Eds.), Geographies of science (pp. 185-197). Knowledge and Space: Vol. 3. Dordrecht, The Netherlands: Springer. doi:https://doi. org/10.1007/978-90-481-8611-2_10 
Withers, C. W. J., Higgitt, R., \& Finnegan, D. A. (2008). Historical geographies of provincial science: Themes in the setting and reception of the British Association for the Advancement of Science in Britain and Ireland, 1831-c.1939. British Journal for the History of Science, 41, 385-415.

Wouters, P., \& Costas, R. (2012). Users, narcissism and control: Tracking the impact of scholarly publications in the $21^{\text {st }}$ century. Utrecht: SURFfoundation. Retrieved from http://researchacumen.eu/wp-content/uploads/Users-narcissism-and-control.pdf

Zhong, C.-B., \& House, J. (2012). Hawthorne revisited: Organizational implications of the physical work environment. Research in Organizational Behavior, 32, 3-22. doi:10.1016/j.riob.2012. 10.004

Zilber, T. B. (2002) Institutionalization as an interplay between actions, meanings, and actors: The case of a rape crisis center in Israel. Academy of Management Journal, 45, 234-254. doi:https:// doi.org/10.2307/3069294

Open Access This chapter is licensed under the terms of the Creative Commons Attribution 4.0 International License (http://creativecommons.org/licenses/by/4.0/), which permits use, sharing, adaptation, distribution and reproduction in any medium or format, as long as you give appropriate credit to the original author(s) and the source, provide a link to the Creative Commons license and indicate if changes were made.

The images or other third party material in this chapter are included in the chapter's Creative Commons license, unless indicated otherwise in a credit line to the material. If material is not included in the chapter's Creative Commons license and your intended use is not permitted by statutory regulation or exceeds the permitted use, you will need to obtain permission directly from the copyright holder. 